\title{
Rockfall susceptibility and runout in the Valley of the Kings
}

\author{
Lukovic Marija $^{1} \cdot$ Ziegler Martin $^{1} \cdot$ Aaron Jordan ${ }^{1} \cdot$ Perras Matthew $^{2}$
}

Received: 17 May 2021 / Accepted: 21 July 2021 / Published online: 9 August 2021

(c) The Author(s) 2021

\begin{abstract}
The UNESCO world heritage site Valley of the Kings or Wadi el-Moluk (و ادي الملوك) near Luxor, Egypt, hosts unique burial places of Egyptian kings and royals from the New Kingdom (c. 1539-1075 BCE) and attracts about 0.5 to 2 million tourists per year. Very steep to subvertical cliffs of Thebes Limestone surround the Valley of the Kings. The rock mass is cut by frequent joints and faults making the cliff walls prone to rockfalls. However, only few rockfall debris are found in the valley, likely due to natural remobilisation by flood events and artificial clearings and excavation works that rendered the natural debris cover over the millennia. This work focuses on rockfall susceptibility and runout and makes use of new high-resolution landscape surface models utilising terrestrial laser scanning. We investigated rockfall release areas by exploring rock mass fractures at 23 cliff segments and analysed the kinematics of potential rockfalls. Furthermore, we estimated potential rockfall deposition areas with CONEFALL supported by nine numerical simulations of single rockfall events using Rockyfor3D. We found that nearly $4500 \mathrm{~m}^{2}(26 \%)$ of the public walking paths and 24 out of 64 tomb entrance areas locate within potential rockfall runout zones.
\end{abstract}

Keywords Rock fractures - 3D rockfall modelling · Cone fall analysis · Limestone cliffs · Terrestrial laser scanning - UNESCO world heritage site

\section{Introduction}

Rockfalls are a common type of extremely rapid landslides, which can endanger lives and damage or destroy infrastructure and archaeological sites (e.g., Varnes 1978; Cruden and Varnes 1996; Saroglou et al. 2012; Hungr et al. 2014; Delmonaco et al. 2014; Pappalardo et al. 2016; Mineo and Pappalardo 2020; De Stefano et al. 2021). According to Varnes (1978), rockfall events involve the detachment of rock mass fragments, which are then transported by gravity through free fall, bouncing, rolling, sliding, and are ultimately deposited on a talus cone or as individual debris deposits (see also Whalley 1984; Guzzetti et al. 2004). Thus, rockfalls can be damaging events, and assessing rockfall potential and past rockfall events are important to analyse potential risks and discuss mitigation

Ziegler Martin

martin.ziegler@erdw.ethz.ch

1 Department of Earth Sciences, ETH Zurich, Zürich, Switzerland

2 Lassonde School of Engineering, York University, Toronto, Canada 


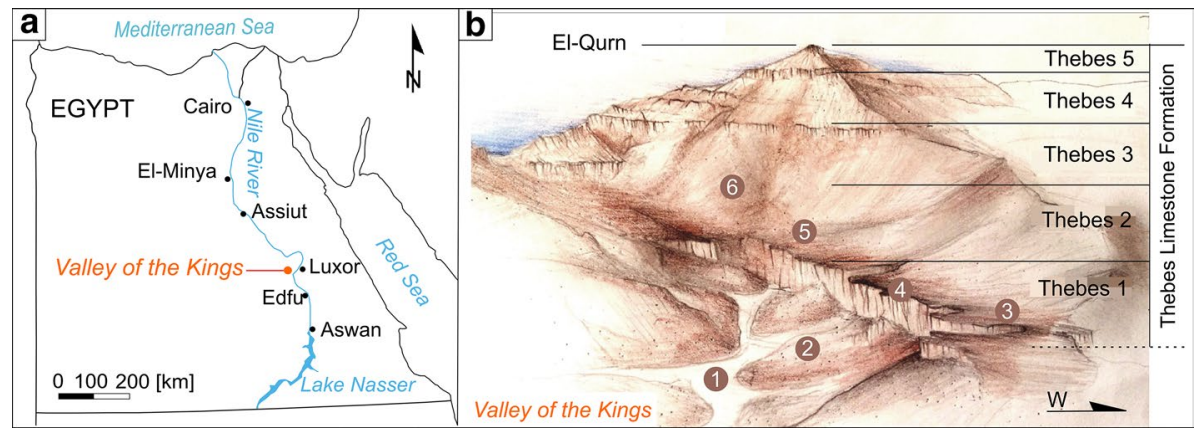

Fig. 1 a Geographical setting of the Valley of the Kings in the Theban Mountains, close to Luxor, Egypt. b The Valley of the Kings is surrounded by about horizontally bedded rocks belonging to the Thebes Limestone Formation. The inner Kings' Valley (1) is surrounded by a first set of steep cliffs of the Thebes 1 sequence (4). At places, slopes (2) lead up to the cliffs that are incised by dry channels (gullies) (3). Finally, the lowermost cliffs are surrounded by a plateau (5) and moderately inclined upper slopes (6) leading to the higher cliffs

strategies. Review works on rockfall hazard assessments are provided by Ferrari et al. (2016), Gerber (2019), and Loew et al. (2021).

Rockfall hazard assessment requires estimating the probability of boulder detachment, the potential area that may be impacted as well as the intensity of impacts. Where temporal probabilities cannot be assessed, as in the present work, investigation of likely initiation zones can be referred to as a susceptibility analysis (Ferrari et al. 2016). Initiation of rockfall events is structurally controlled (e.g., Volkwein et al. 2011; Corominas et al. 2018), and failure is often through planar sliding, wedge sliding, or toppling, which can be assessed based on kinematic analyses (e.g., Wyllie 2014; Matasci et al. 2018). Once initiated, the detached boulders often experience a period of free fall, before impacting the path substrate and bouncing, rolling, and sliding until deposition (e.g., Dorren 2003; Volkwein et al. 2011). Rockfall transport is strongly influenced by the shape of the detached boulder, as well as the slope angle, substrate material and roughness (including any obstacles such as trees) encountered along the path (Dorren 2003). Individual rockfalls often fragment during transport, can reach velocities of many meters per second, and thus have large destructive potential. The potential area that may be impacted by rockfall, as well as intensity of impacts, can be assessed with empirical and numerical methods (e.g., Dorren 2003; Hungr et al. 2005).

This work investigates rockfall susceptibility and runout in the Valley of the Kings in Egypt or Wadi el-Moluk (و ادي الملوك), referred to herein as 'the Kings' Valley' (KV) or 'the Valley' (Fig. 1a). To the authors' knowledge, no comprehensive rockfall investigations have been conducted or made available in this famous cultural heritage site, ${ }^{1}$ which attracts on average about 1.5 million tourists each year (Demas and Agnew 2012). In 1979, UNESCO declared the Kings' Valley as a World Heritage Site. The very steep, ${ }^{2}$ partly

\footnotetext{
1 The nearest investigated location, where detailed structural analysis took place, was at the Temple of Hatshepsut (Abdallah and Helal 1990).

${ }^{2}$ For dip angles we use the terminology of the Austrian geologist E. Clar $(* 1904 \dagger 1995): 0^{\circ}=$ horizontal; $1-24^{\circ}=$ flat to gently dipping; $25-44^{\circ}=$ moderately steep; $45-74^{\circ}=$ steep $; 75-89^{\circ}=$ very steep; $90^{\circ}=$ vertical).
} 
overhanging cliffs of the Valley surround 64 tombs of Egyptian kings and royals from the 18-20th dynasties that have been buried during the New Kingdom (c. 1539-1075 BCE) (Aubry et al. 2009). Considering the historical importance of the site and the large number of visitors, the cliffs not only create an impressive setting but also, as a rockfall source area, a potential threat to people and tombs. In addition to natural processes such as infrequent rainstorms and long-term, natural rock weathering, the large numbers of day visitors also cause deterioration of the site, both inside the tombs and on the surface around the excavated areas (Wüst and McLane 2000). In 2000 and 2002, the Kings' Valley was part of the World Monuments Watch project that aims at conserving architectural sites of important historical heritage. ${ }^{3}$

This research includes high-resolution terrestrial laser scanning of the inner Kings' Valley, combined with digital photographs, to create a three-dimensional surface model of the site. We explored this model to assess both the initiation and transport of rockfalls at this site. In particular, we (i) identify important rock mass fractures at slopes and cliffs, (ii) locate past and potential new rockfall source areas and estimate their sizes, and (iii) determine the spatial extent of the impact of past rockfalls. We used field mapping to further assess rockfall affected and depositional areas, and numerical rockfall simulations, using CONEFALL and Rockyfor3D, to investigate rockfall runout at the large scale and at selected, critical sites. The results are a geological map as well as maps of rockfall susceptibility and runout, which can help in mitigating any material or human losses in the future and improve archaeological mission safety.

\section{Geological and morphological setting of the Valley of the Kings}

The Kings' Valley is located about $180 \mathrm{~m}$ a.s.l. on the West Bank of the Nile River in the Theban Mountains of Upper Egypt, about $12 \mathrm{~km}$ from Luxor (Fig. 1a). The Valley has a NNW-SSE trend and a length of about $1 \mathrm{~km}$. The inner Kings' Valley hosts most of the archaeological sites and is surrounded by hillslopes with steep cliffs (Fig. 1b). The highest peak (420 m a.s.1.) of the Theban Mountains, called El-Qurn (القرن, lit. trans. "the horn"), is located south of the Valley. The Valley and its tributary valleys cut through subhorizontally bedded rock units of the Esna Shale and Thebes Limestone Formations. These are made of shales, marlstones, and limestone deposited during the Upper Palaeocene and Lower Eocene (Said 1962). The lower-lying Esna Shale Formation outcrops in deep tombs (e.g., Horemheb - KV57 $7^{4}$ (Hemeda 2021), Royal Tomb of Seti I-KV17, or Ramesses XIKV4 (Wüst and McLane 2000)) and at the surface in the lower parts of the Valley, while the cliffs to the top of El-Qurn, including our research area, consist of units of Thebes Limestone Formation (Fig. 1b).

The Thebes Limestone Formation was subdivided into multiple units by various authors (Said 1960; Curtis 1979; Wüst 1995; Tawfik et al. 2010; Dupuis et al. 2011; King et al. 2017). The units contain massive, bedded, and nodular (micritic) limestones, as well as marlstones. The original sediments were deposited during the Lower Eocene (Ypresian) in a neritic (as deep as $200 \mathrm{~m}$ ), warm, open marine environment (King et al. 2017; Abou ElAnwar et al. 2018). The entire stratigraphic succession can be explored at El-Qurn (Tawfik

\footnotetext{
3 www.wmf.org/project/valley-kings; accessed on May 4th, 2021.

4 Tombs in the Valley of the Kings are labeled as KVn, where KV stands for Kings' Valley and n represents the number of the tomb.
} 


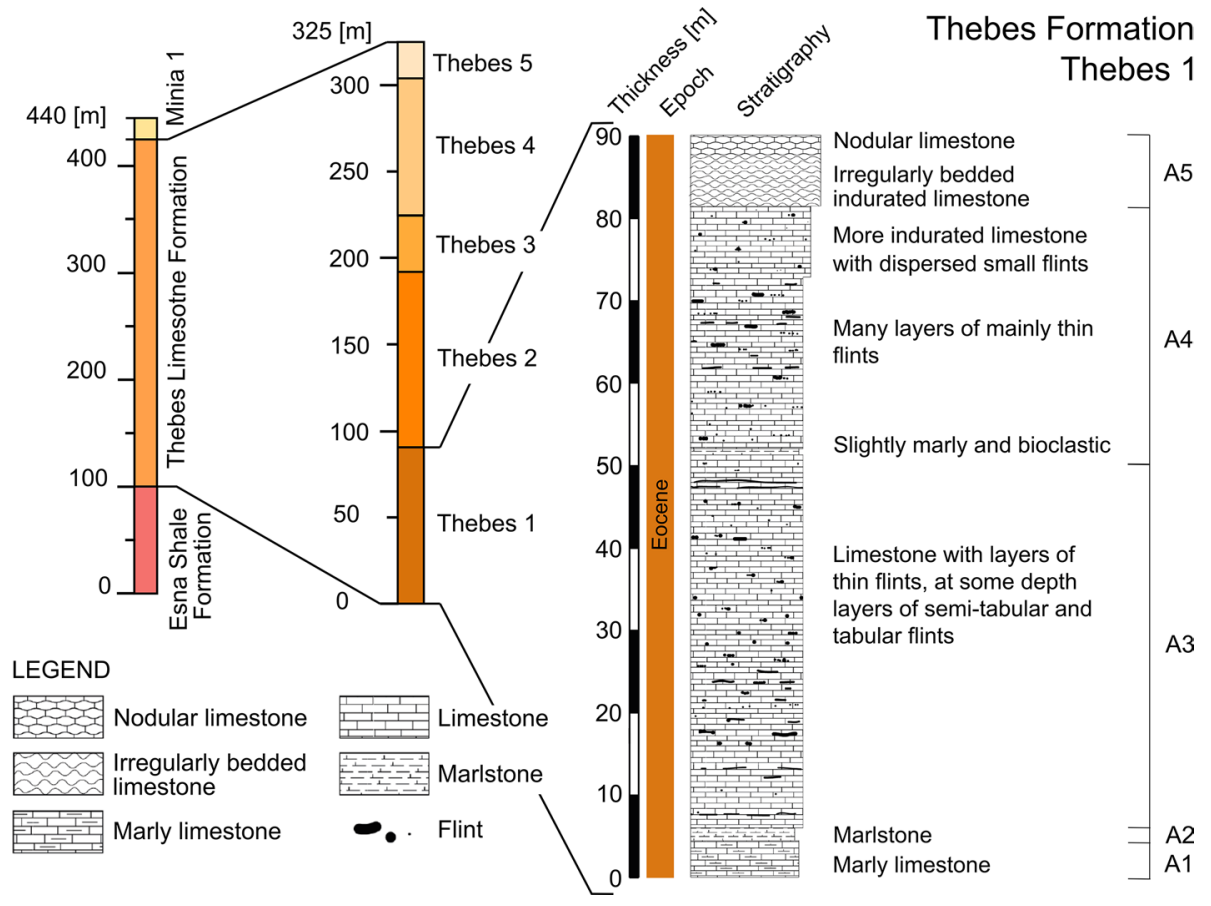

Fig. 2 Thickness and lithological description of the Thebes 1 sequence (i.e., unit A) modified after King et al. (2017). Unit A contains marlstones to marly limestone at its bottom, limestones with layers of flints, and irregularly bedded to nodular limestones at its very top

et al. 2010; Dupuis et al. 2011), where the individual units form a stepped morphology with very steep cliffs separated by gently dipping slopes (Fig. 1b).

King et al. (2017) provided the most recent and detailed stratigraphic description, including lithological markers for each unit of the Thebes Limestone Formation, which they divided into five sequences (Thebes 1-5; Fig. 2) made of twelve units (A-L) that form five cliffs. The individual units differ in lithology, structure, and depositional environment (from shallow marine to neritic). Within the borders of our research area, the approximately $90 \mathrm{~m}$ thick Thebes sequence 1 is outcropping and refers to subunits A1-A5 according to King et al. (2017). The greatest difference lies between units A1-A4 and A5, i.e., the transition from massive marly limestone with flints to irregularly bedded (and nodular) limestones (Fig. 2). Rocks of the Thebes 1 sequence build the lowermost cliffs of the Valley (Fig. 1b). In this study we simplify unit A and distinguish i) massive marly limestone with a total thickness of about $80 \mathrm{~m}$, thus combining subunits A1-A4, and ii) irregularly bedded (and nodular) limestone exhibiting a maximum thickness of about $10 \mathrm{~m}$, i.e., subunit A5. The $\sim 100$-m-thick sequence Thebes 2 consists of marlstones with scattered bands of flint concretions and abundant pelecypods. Its lower portion forms the first morphological step (Fig. 1b). Thebes 3 is made of fossil-rich limestone and is about $35 \mathrm{~m}$ thick. Thebes 4 consists of $70 \mathrm{~m}$ stratified limestones. Finally, Thebes 5 is a yellowish, silicified limestone with a thickness of about $30 \mathrm{~m}$. According to King et al. (2017) the rocks of the Thebes Limestone Formation are overlain by the Minia Formation (unit M). On top of the rock formations terrestrial detrital deposits, such as conglomerates and breccias, of 
Pliocene to Pleistocene ages occur (Aubry et al. 2007, 2009; Dupuis et al. 2011), e.g., at the entrance area in the north-eastern part of the Valley.

According to Dupuis et al. (2011), some partly hidden tectonic faults form a graben structure crossing the cliff top (near KV9) and base of the Valley with NW-SE strike direction (cf., Aubry et al. 2011: Fig. 10). The structure was first mentioned by Curtis (1979) referred to as the "Valley of the Kings Fault". According to a projection of this normal fault to the South by Wüst and McLane (2000), the Kings' Valley fault may displace the Member I of the Thebes Limestone Formation by a maximum of $30 \mathrm{~m}$ close to the tomb of Seti I (KV17) with foot wall in the South. In addition, there are several listric and other normal faults in the West and North-West of the Valley (Aubry et al. 2011; Wüst 1995). According to Abdallah and Helal (1990) and Wüst (1995), the Thebes Limestone Formation is cut by two systematic, conjugate subvertical joint sets, striking N-S and W-E. Finally, Wüst (1995) mentioned unsystematic exfoliation joints (elsewhere referred to as sheeting joints; e.g., Ziegler et al. 2013, and references therein) that he related to stress changes caused by erosion of past clastic sediments during pluvial episodes.

The inner Kings' Valley is surrounded by moderately steep hillslopes to vertical cliffs (Fig. 1b). The maximum distance between the inner valley's cliffs is approximately $600 \mathrm{~m}$ and the maximum difference in altitude between the Valley's floor and the peak of El-Qurn is $240 \mathrm{~m}$. The exposed top part of the cliffs including the cliff faces are a prime zone of erosion. Loosened material is transported by gravitational and infrequent fluvial processes and deposited just below the steep slopes. At places, gently dipping hill slopes and debris cones lead up to the top of the lower cliff. In the southern portion of the Valley, this pattern repeats at higher cliffs, from Thebes 2 until Thebes 5 (Fig. 1b).

The morphology of the Valley developed primarily due to fluvial erosion and gravitational rock mass wasting processes such as rockfalls or slides (Bunbury 2016). The Theban Mountains reveal a series of dendritic wadis with a wide range of incision depth and width, of which the Valley is one example. The wadis' positions and orientations are mainly controlled by the rock mass structure and lithology (Yehia et al. 1982). Dry channels, also referred to as gullies (Fig. 1b), are reactivated during infrequent, intense rainfall events leading to flooding of the Valley every few tens of years on average (Cross 2008, and references cited therein; McLane et al. 2003; Ogiso et al. 2017). Most of these floods occurred in October, commonly the wettest month of the year. Finally, the hot desert climate (classified as BWh: B(arid), W(desert), $h(h o t)$, according to the Köppen (1936) climate classification; cf., Alcaíno-Olivares et al. 2020) with its daily and annual temperature cycles of considerable amplitudes contributes to the rock mass deterioration.

\section{Methodology}

\subsection{Terrestrial laser scanning (TLS) and data processing}

Rockfall susceptibility and runout analyses require a high-resolution 3-D model, which allows precise structural and topographic assessments. To create such a model, we used a FARO Focus $120 \mathrm{~S}$ terrestrial laser scanner for geodetic landscape surface acquisition of the inner valley during our field season from January 6th to February 18th, 2019. ${ }^{5}$

\footnotetext{
${ }^{5}$ Note that also Porcelli et al. (2020) from a different mission used laser scanning in the Valley.
} 
The scanner has a $360^{\circ}$ laser distance range of maximum $120 \mathrm{~m}$ and the capability to capture photographs, which were used later for remote mapping and viewing of sites of interest. The limited range of the scanner required a dense network of scan positions so that the scanned surfaces had sufficient overlap to construct a high-quality model that minimised gaps. Besides the quantity of scans, the distribution of scan locations was the second most important factor, especially where the line of sight changed within short distances such as in narrow gullies. At places, the scan locations were as dense as $10-15 \mathrm{~m}$. Scan locations and timing were planned roughly during a desk study considering possible difficulties in achieving undisturbed scans at busy places with tourist traffic in the inner valley. Priority was given to cliff regions, and surfaces near public walking paths were scanned afterward. Finally, an area of about $0.27 \mathrm{~km}^{2}$ was covered with 740 scans with each scan having a ground resolution of about $1 \mathrm{~cm}$.

We registered and merged individual point clouds successively using Autodesk ReCap and georeferenced the 3-D models using 13 ground control points, which were surveyed using a Leica Zeno CS15 field GNNS device in the UTM $36 \mathrm{~N}$ coordinate system. Besides a valley-size Digital Elevation Model (DEM) of $10 \mathrm{~cm}$ resolution (Fig. 3a) we processed three smaller-size models (called segments 1-3, Fig. 3a) of specific areas in the Valley of $1 \mathrm{~cm}$ resolution. Raster data interpolation and construction of contour, slope, and hill-shaded maps were carried out with ESRI ArcGIS (Fig. 3b). The large model was used as a base for geological and runout maps, while the detail models were used for structural mapping of the cliffs. In addition, in the same season we took many thousands of overlapping photographs for geologic interpretations and to receive a photogrammetric model of the surroundings of the inner valley's cliffs for flash flood hazard analyses. The latter is not part of this work.

\subsection{Geological mapping of rock debris and past rockfall release areas}

The Kings' Valley contains large amounts of artificial fill and excavated material, which is widely distributed throughout our study site. Thus, we first distinguished naturally deposited rock materials from active excavation zones and gathered information from Paulin-Grothe and Bickel (2019, pers. comm.) about past excavation activities in the Valley. The selected mapping scale of 1:1500 allowed for accurate mapping of relevant colluvial features (e.g., debris material and deposited blocks). Rock debris was divided into (i) debris made of angular limestone fragments $(\mathrm{mm}-\mathrm{cm})$ with light beige flint fragments, (ii) debris with dark flint fragments (up to tens of $\mathrm{cm}$ ), (iii) consolidated debris (boulders within a finer matrix), and (iv) yellowish-brown, poorly graded fine sand (aeolian sediments).

To investigate past rockfall events, we mapped deposited blocks $(d>0.5 \mathrm{~m})$ as an individual unit. The description includes rock type, size, and distance from the cliffs measured using the 3-D models. Besides searching for deposited blocks, we identified possible release areas on the cliff surfaces. For the latter analysis, we mapped scarps that followed specific criteria: 1 . Estimated outbreak volumes are larger than $0.0156 \mathrm{~m}^{3}$ (conforming to cubic blocks of $0.25 \mathrm{~m}$ edge lengths), 2. Release surfaces are formed by clear fracture planes, 3 . Release surfaces are fresh and of brighter colour compared to weathered surfaces that are darker. Volume estimates were made by investigating the geometry of fracture planes and likely block shapes. 


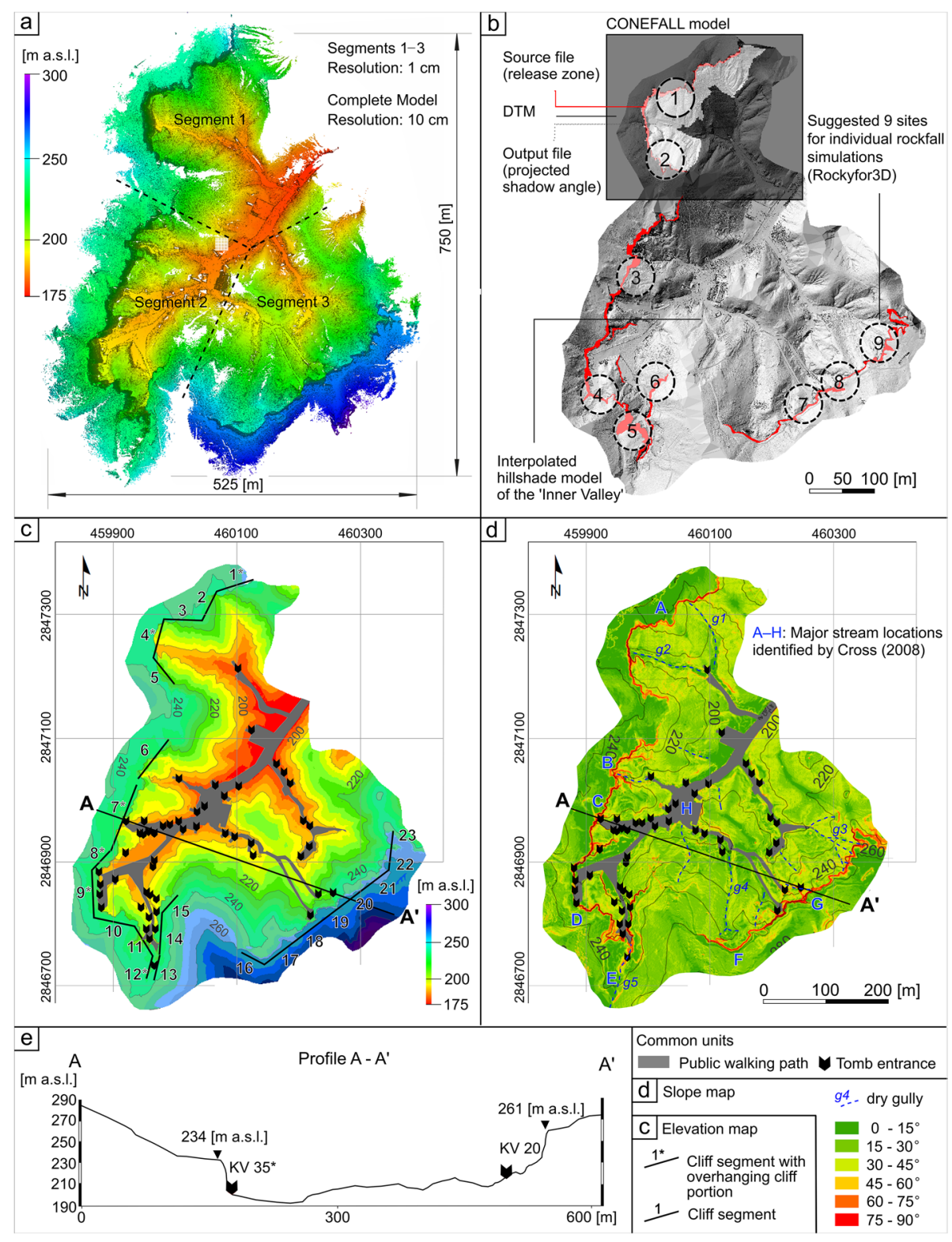

Fig. 3 a 3-D point cloud from terrestrial laser scans (10 cm resolution). b Interpolated, hillshaded map $(10 \mathrm{~cm}$ resolution) of the Valley. Zones of potential rockfall release areas (red) are given, together with an example polygon of the analysis in CONEFALL, including the marked locations (1-9) for numerical simulations using Rockyfor3D. c Elevation map of the Kings' Valley with numbered cliff segments and profile A-A'. Cliff segments with overhanging portions are marked with (*). d Classification of slope angles, showing steep, partly overhanging cliffs (red) together with tourist walking areas (grey) and tomb locations. e Profile A-A' highlighting the different cliff altitudes between the west and east parts of the Valley and position of tomb entrances below cliffs 


\subsection{Analysis of rock mass discontinuities and rockfall release mechanisms}

Mapping of discontinuities along the $\sim 1.4-\mathrm{km}$-long cliffs was conducted in the Valley to identify where potential rockfall release areas are located, which fractures contribute to release zones, and to determine the main release mechanisms. For this mapping, we subdivided the cliffs into 23 segments based on their orientation. Most cliffs contain massive marly and irregularly bedded to nodular limestones. Overview observations were made in the field, and then the created 3-D models of $1 \mathrm{~cm}$ resolution were used to systematically map the cliffs in more detail. CloudCompare was used for digitisation and orientation analysis of fractures.

Each cliff segment was assessed separately, and only discontinuities with a persistence larger than $0.5 \mathrm{~m}$ were considered for further analysis. Fracture orientations were finally analysed with RocScience Dips 7.0. We used the cliff orientations to conduct Terzaghi weighting and applied a search angle of $30^{\circ}$ to identify fracture orientation sets. Rock mass structural and kinematic analyses included a total of 1794 fractures at the 23 cliff segments. Parameters such as fracture weathering, roughness, and infilling demand close-up observations and were limited due to the height of the cliffs and model resolution. These parameters were only qualitatively described during the field observations where possible. The mapped rock mass discontinuities included rock bedding, joints, faults, and tension cracks. Finally, we included major faults in our geological map.

For each cliff segment, we conducted a kinematic analysis with Dips to obtain the probabilities for planar sliding, wedge sliding, and toppling using the cliff segments' average dip and dip directions and the identified joint sets at the cliffs. The probability of failure can be used as an indication of rockfall susceptibility at a given location, and similar approaches have been used by other authors (e.g., Matasci et al. 2018; Pérez-Rey et al. 2019). We analysed the number of joint sets that form critical intersections and identified critical sets on each cliff segment that can contribute to failures. Sets were obtained in the same way for each individual cliff segment as described above for the entire dataset and Terzaghi weighting was applied in the probabilistic analyses. The cliff segments' orientations and identified joint sets are given in Table 1 . All analyses assumed persistent, planar joint planes with a constant friction angle of $25^{\circ}$ (i.e., similar to values of limestone fractures without infilling given by Barton 1974). Thus, the influence of rock bridges was not included in the analysis, a point discussed in Sect. 5.2, when presenting potential triggers. For the wedge failure only critical intersections of mean set planes were considered. For planar sliding failure all joints mapped at the cliff segment and joints in sets of the cliff segment were investigated. Furthermore, we considered planar failure to only occur if the dip direction of the joint and joint set planes were within $25^{\circ}$ of the cliff's dip direction (Hudson and Harrison 1997). In addition, we assumed that lateral release planes exist (e.g., joints, tension cracks) so that planar sliding failure on a single fracture can occur. Finally, for toppling failure to occur, we searched for critical mean set plane intersections that plunge into the slope and form toppling blocks and a third joint set that acts as a basal release plane allowing a block to topple (Hudson and Harrison 1997).

\subsection{Analysis of potential runout zones}

Our analysis of potential new rockfall runout focused on defining the runout distances and potential deposition areas (e.g., Katz et al. 2011; Palma et al. 2012; Jaboyedoff et al. 


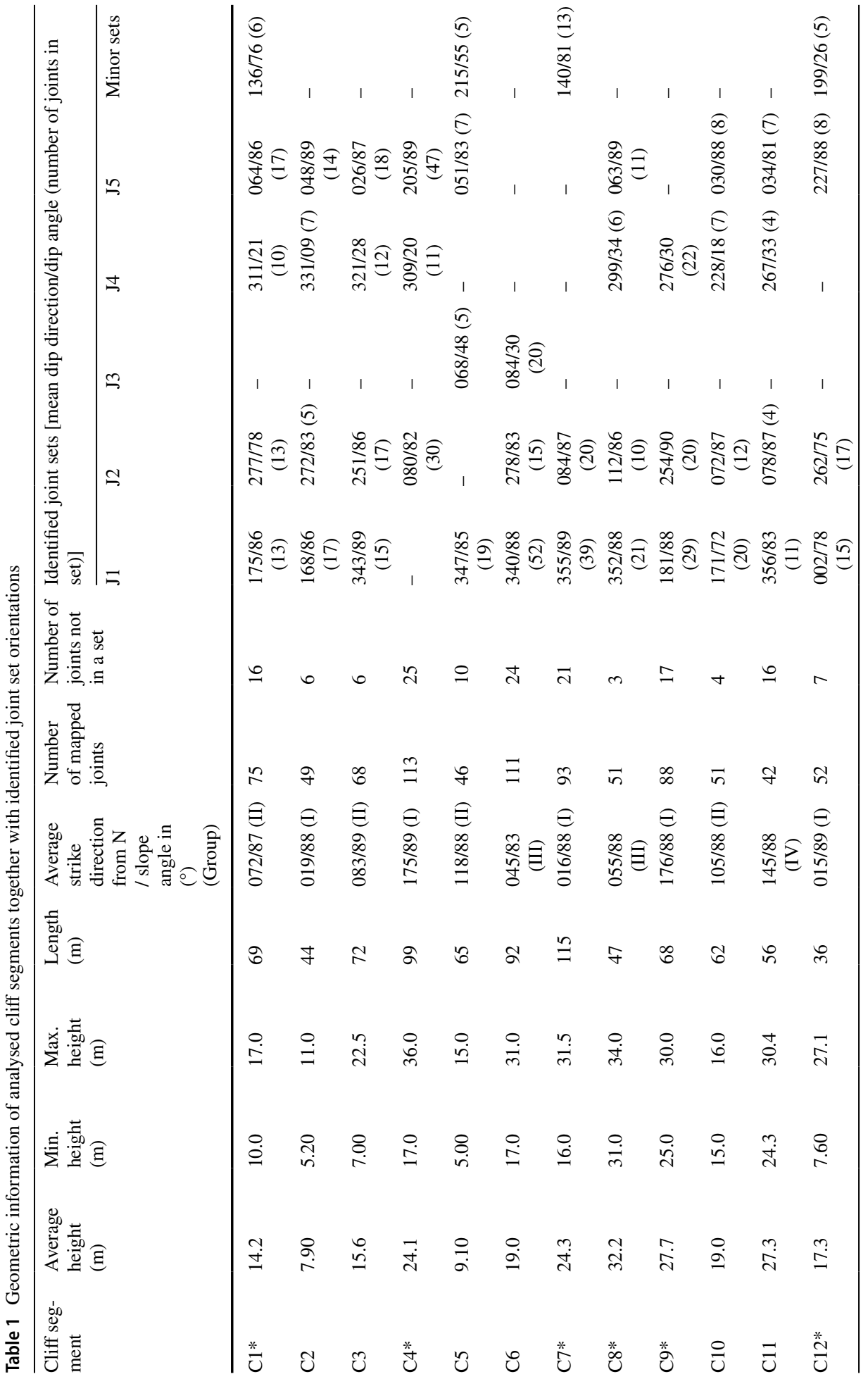




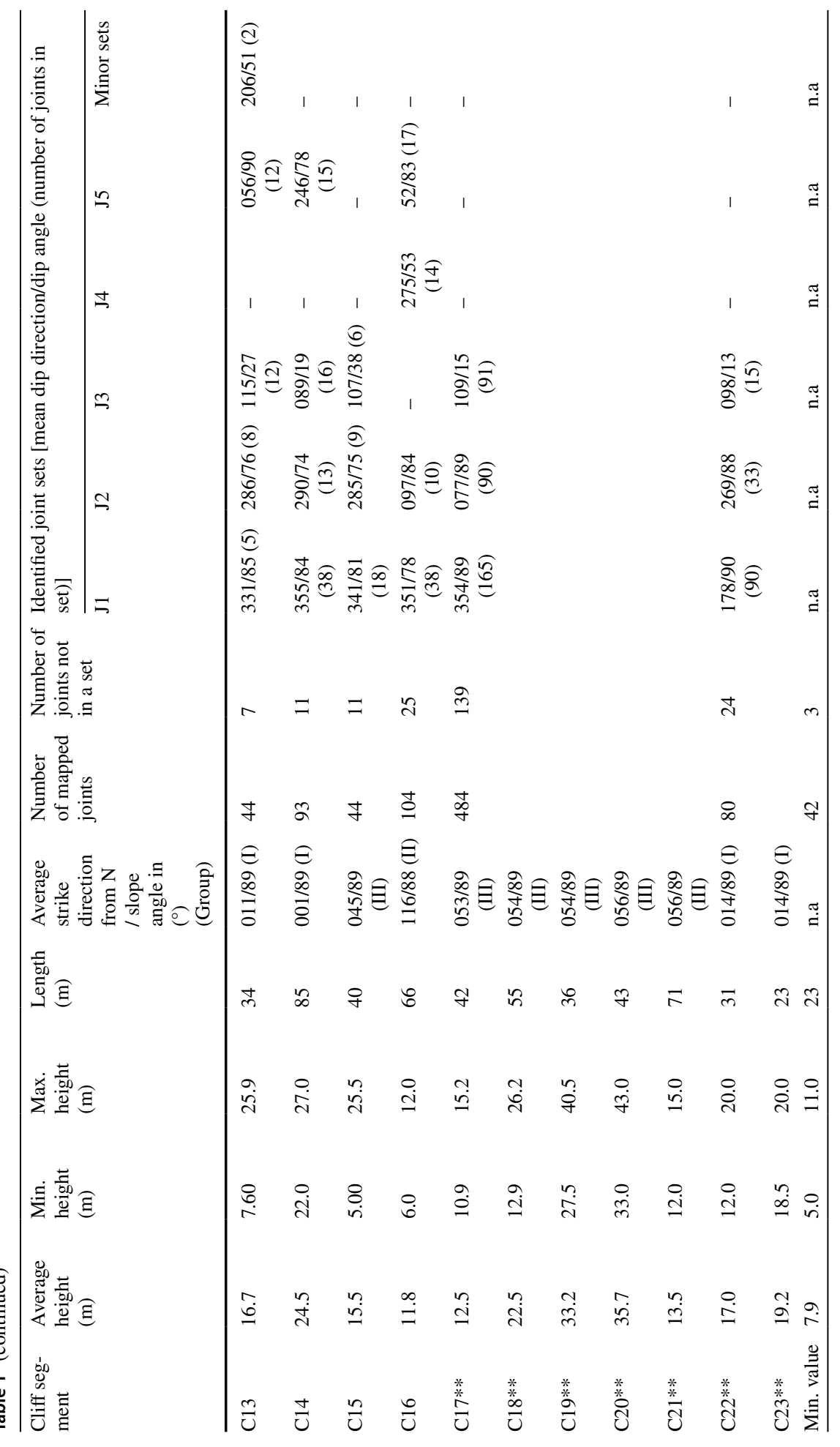




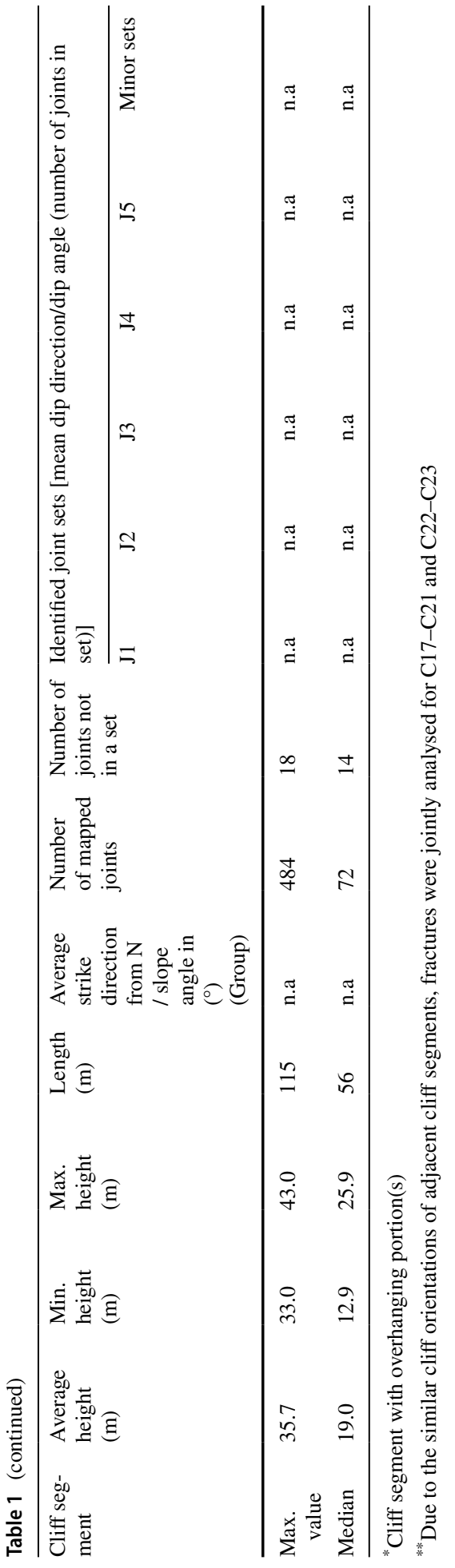


2005). Rockfall depositional areas were assessed at two spatial scales (Fig. 3b), for the entire Valley and for nine critical locations. The method that involved the entire research area was based on estimation of the shadow angle of rockfalls (Wieczorek and Snyder 1999; Evans and Hungr 1993; Lied 1977; Jaboyedoff and Labiouse 2003; Guzetti et al. 2003). The concept of shadow angle stems from observations of the so-called Fahrböschungswinkel (Ger.) or reach angle described for rock avalanches by Heim (1932) and was estimated using the software CONEFALL (e.g., Ghazipour et al. 2008; Loye et al. 2008; Jaboyedoff and Labiouse 2011). For the nine critical locations, the numerical simulator 'Rockyfor3D' was used, described in more detail below (Dorren et al. 2006).

Estimation of the shadow angle was carried out for the cliff portions marked in red in Fig. 3b, subdivided into four zones (see example zone highlighted in Fig. 3b), by connecting the line starting from the furthest deposited material to the release zone. In our study we selected the top of the cliffs as release zones because most of the rockfall debris originated from irregularly bedded to nodular limestone located at the top part of the cliffs (Sects. 2 and 4.2). A range of shadow angles from $27^{\circ}$ to $37^{\circ}$ (also referred to as energy line angle) was then applied on the entire site and after visual inspection the shadow angle covering all mapped deposits was taken as the best estimate. Estimations of shadow angles vary for different sites (e.g., Onofri and Candian 1979; Evans and Hungr 1993), usually within a range from $27^{\circ}$ to $37^{\circ}$ (Jaboyedoff and Labiouse 2011). Since the results must correspond to the field conditions, the reliability of this method depends on the slope morphology and quantity of preserved past events. Locations of deposited past rockfall debris were mapped in the field and utilising the 3-D models (Sect. 3.2) and used for the calibration of the shadow angle. Blocks that were likely remobilised by flooding events were noted but excluded in this analysis.

Projected runout distances around the cliffs, obtained from the shadow angle method, were further verified by numerical simulations of single block fall trajectories. We identified and characterised the geometry of potential unstable zones (i.e., rock volumes with widely open fractures or within moderately weathered rock mass, and detached rock portions resting on inclined discontinuity planes). Out of these we selected nine locations for rockfall trajectory simulations using Rockyfor3D (Dorren et al. 2006) (Fig. 3b). In the Valley there are many more potentially unstable zones at the cliffs, but application of this method was not to predict each event but to support previous assessment of the potential deposition areas. The main criteria for selecting the nine sites for simulation were i) a close vicinity to the tombs and public walking path and ii) a good distribution across the Kings' Valley's cliffs to test the estimated boundaries obtained from the shadow angle analysis.

Rockyfor3D assumes that no fragmentation occurs during runout, that the tangential restitution coefficient is a random function of the mean obstacle height, and that block fall direction has a random downslope component, the latter two of which lead to a range of simulated trajectories (Dorren et al. 2006). To parameterise the model, we input ten raster map types including information on DEM, rock density, size of release areas, block shape, ground surface roughness and soil cover, the last of which determines normal coefficients of restitution (Dorren et al. 2006). The raster maps in ESRI ASCII Grid format had to have the same extents and cell sizes. Parameters were defined during the field work by estimating the shape and dimensions of deposited blocks, slope surface roughness and soil types. After computing the simulations, the main output raster data crucial for this research was the estimated reach probability. This dataset shows the probability that a rockfall passes through each given cell. 


\section{Results}

\subsection{Setting of the investigation area}

\subsubsection{Morphological characterisation}

The elevation map calculated from TLS includes both natural and anthropogenic features, such as waiting areas at tomb entrances and public walking path (Fig. 3c). The latter make up $6.3 \%\left(0.017 \mathrm{~km}^{2}\right)$ of the total surveyed area of $0.27 \mathrm{~km}^{2}$. Excavation areas at the time of mapping covered another $5.5 \%\left(0.015 \mathrm{~km}^{2}\right)$ of the Valley.

Following the opening of the Red Sea rift with associated bedrock uplift and incision of the Palaeo-Nile from the Oligocene onwards (Fielding et al. 2018; Bosworth et al. 2005), fluvial erosion and rock mass wasting processes along predisposed structural features (e.g., tectonic fractures) shaped the Kings' Valley. The most prominent features of the natural landscape are gently dipping to almost flat slopes above the inner cliffs (Fig. 1b: feature 5), subvertical to overhanging inner cliff walls (best seen as red zones on the slope map; Fig. 3d; Fig. 1b: feature 4), steep and narrow channels (gullies) reaching from the cliff tops down to the main public walking paths (Fig. 1b: feature 3; cf., stream-flow diagram by Cross 2008: Fig. 1), moderately steep hills (average slope angles of $30^{\circ}$ ) in front of some cliff segments (e.g., C1, C5, C7, C15, C20, C22, C23; Fig. 1b: feature 2), and branching channels, mostly used as public walking paths, in the Kings' Valley's bottom that are gently inclined $\left(<10^{\circ}\right)$ (Fig. 3c, d).

The focus of our research lies on the cliff segments as rockfall release areas and on depositional areas in the inner valley. Table 1 summarises the cliff segments' geometric properties. Cliff heights range from about $5 \mathrm{~m}$ to $43 \mathrm{~m}$. Some of the subvertical cliffs are overhanging or have overhanging portions (e.g., C1, C4, C7-C9, C12), presenting potential release zones for free falling blocks with high kinetic energy.

Much of the surveyed landscape's natural debris cover has likely been modified or removed during ancient tomb construction works and by modern archaeological excavations. The latter is supported by previous work conducted during archaeological campaigns (e.g., by Howard Carter, Theodore M. Davis, Theban Mapping Project, Amarna Royal Tomb Project, Kings' Valley Project) and by comparison of the inner Kings' Valley with, e.g., the neighbouring Western Valley (Wadi al-Gurud) or debris located at higher elevation, outside the inner valley. Additionally, clearings of past flash flood deposits (e.g., from the flood of 1994 with rainfall intensity of $16 \mathrm{~mm} / \mathrm{h}$; Ogiso et al. 2017) contributed to a changing landscape. Nevertheless, the Valley contains some gullies with partly preserved debris, which likely originated from rockfalls or was remobilised during heavy rainfalls (Sect. 4.2). The lengths of the longer gullies (labelled as $g 1-g 5$ ) range from approximately $100 \mathrm{~m}(\mathrm{~g} 3)$ to $140 \mathrm{~m}(\mathrm{gl})$. The steepest gully with a maximum slope of $30-40^{\circ}$ is $\mathrm{g} 3$, located below cliff sections C22 and C23 (Fig. 4).

\subsubsection{Lithological characterisation}

We compiled our field mapping results in the form of a generalised geological map (mapped at 1:1500; Fig. 4). This map agrees well with the map of Gander and Gugger (1996) of 1:5000 scale in terms of tectonic faults and general distribution of lithological units but is more detailed due to its larger scale. Debris deposits of Pliocene and 


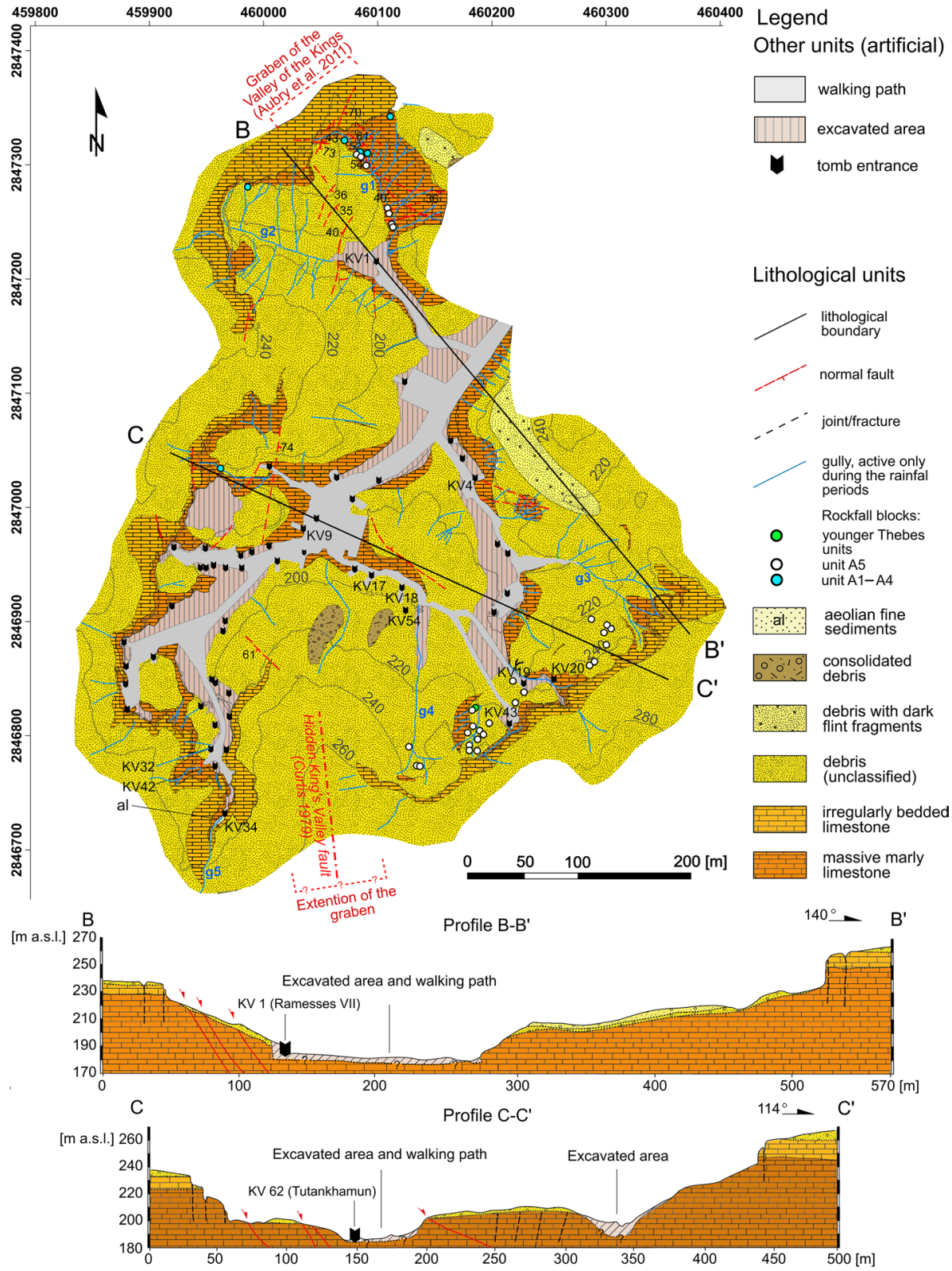

Fig. 4 Simplified geological map of the inner Kings' Valley. Public walking paths and active excavation zones in the time of our field research are highlighted (past excavation activities are not included). Profiles $\mathrm{B}-\mathrm{B}^{\prime}$ and $\mathrm{C}-\mathrm{C}^{\prime}$ show the difference in the cliff altitudes on the valley's sides and indicate steep joints and faults mapped within the Valley

Pleistocene age (Wüst 1995) cover much of the sedimentary rock sequence until the top of El-Qurn so that bedrock outcrops are limited to steep cliffs, portions of channels, and artificial rock cuts. The oldest natural rock outcrops are massive marly limestones of unit 

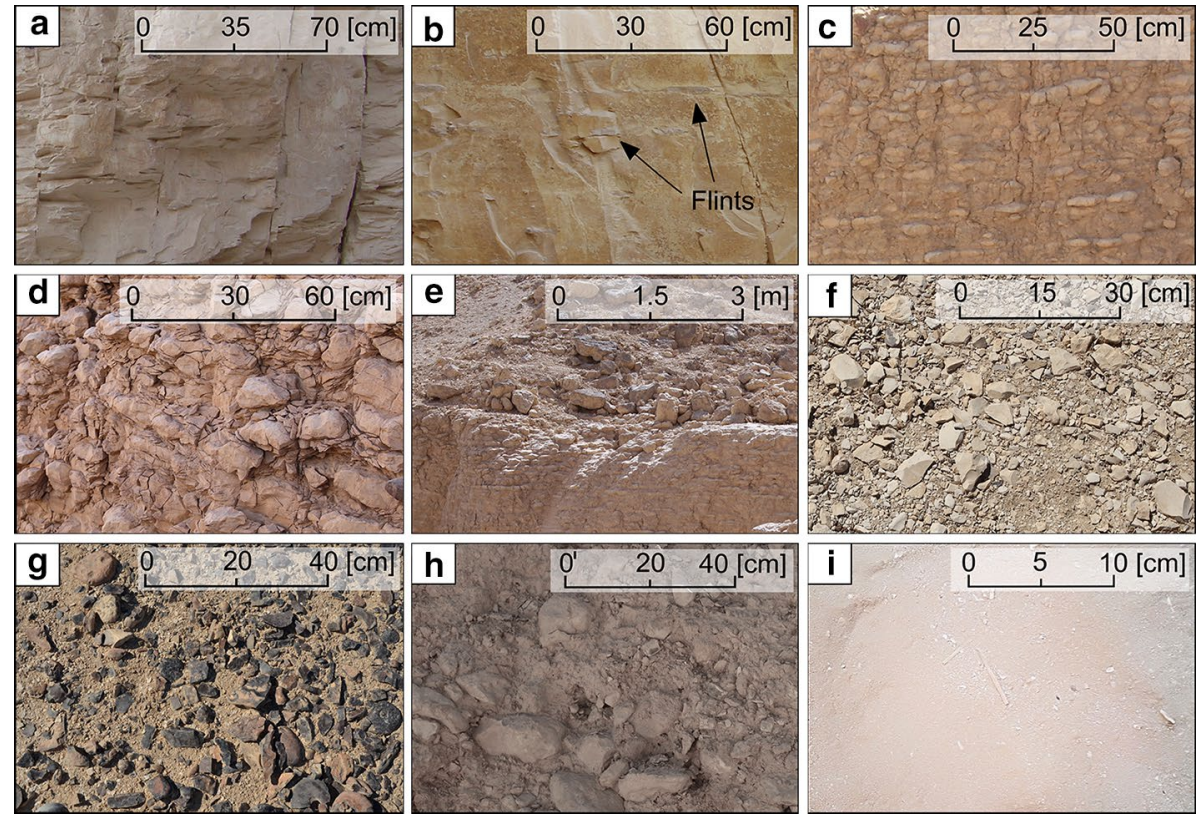

Fig. 5 Example photographs of distinguished bedrock and debris. a fractured marly limestone of the lowermost part of the Thebes 1 sequence, $\mathbf{b}$ massive marly limestone with isolated flints (arrows), $\mathbf{c}$ irregularly bedded limestone, $\mathbf{d}$ weathered nodular limestone, e deposited blocks at the top of the cliff 1 , $\mathbf{f}$ debris with angular limestone and flint fragments, $\mathbf{g}$ debris with dark angular flint fragments, $\mathbf{h}$ consolidated debris of angular to partly rounded very small-medium blocks, and $\mathbf{i}$ fine aeolian sediments

A of the Thebes I sequence (King et al. 2017; Fig. 4), except some shallow outcrops of the Esna Shale Formation at the entrance area and road to the Kings' Valley. Massive marly limestone is present within the Valley in the incised channels, cliffs, near the walking path and excavated areas. Weathering of this unit is not homogeneous along the cliff face; it can vary from slightly to moderately weathered according to the ISRM (1981) classification scheme.

All tomb entrances are in unit A of the Thebes I sequence. 12 out of 64 tomb entrances are located right below to within approximately $10 \mathrm{~m}$ from the cliff faces. The remaining tomb entrances are located at lower altitudes and more in the centre of the Valley. The lowermost part of the rock sequence contains intercalation of marlstone and marly limestone (Fig. 5a) and this rock mass is blocky according to the Geological Strength Index (GSI) classification (Marinos et al. 2005), and is more fractured than the overlying massive marly limestone (Fig. 5b). Massive marly limestone contains heterogeneously distributed tabular flint layers but also zones of dispersed flint fragments. The top portion of the cliff surrounding the inner valley exposes irregularly bedded to nodular limestone (Fig. 5c,d), which has the least amount of metre-scale or larger fractures, consistent with fracture mappings of nodular and massive limestones at Sheikh 'Abd el-Qurna by Ziegler et al. (2019). Fresh to slightly weathered nodular limestone shows a greater erosional resistance on a cliff profile compared to the adjacent, stratigraphically lower and higher rock masses (Fig. 2; cf., Ziegler et al. 2019). The inner cliffs are overlain by in situ weathered rock mass (Fig. 5d) as well as loose debris and rock boulders that belong to younger Thebes sequences (Fig. 5e). 
Debris material made of angular limestone fragments and light-coloured flint fragments are well-graded, ranging from pieces of a few millimetres to tens of centimetres edge length (Fig. 5f). Such debris material can be the result of in situ physical rock weathering and fluvial mobilisation over short distances, or it can originate from the royal tomb excavations (e.g., at hills above KV18 or below KV64; Paulin-Grothe and Bickel (2019, pers. comm.)). No further subdivision was attempted, except that debris with predominantly dark, brownish to black angular flint fragments was distinguished (Fig. 5g). The typical sizes of these fragments range from few centimetres to few tens of centimetres. This debris is located mostly on the top of the slopes and hills in the northern and north-eastern part of the investigation area (Fig. 4). Consolidated debris was found mostly in the southern area of the hill slope above the tombs KV17 and KV18 (Fig. 4; Fig. 5h). It consists of limestone pebbles to rounded boulders with a sandy, compact matrix. These debris could be interpreted as remobilised flooding deposits. Wind-blown sediments were found in depressions and as a filling in open fractures (Fig. 5i). These are poorly graded fine sands of pale yellowish to brown colour, mostly present in the South, between the narrow channel g5 within the cliffs $\mathrm{C} 12$ and C13, near the tomb KV34 (Fig. 4). In most places the thickness of this unit was too small to be considered on the map. Finally, bigger blocks with $\mathrm{dm}-\mathrm{m}$ edge lengths and smaller rock fragments of massive marly limestone and irregularly bedded nodular limestone were found and likely originated from the degraded cliff surfaces as rockfalls (Sect. 4.2; Fig. 4).

\subsection{Spatial distribution and description of past rockfalls and rockfall scarps}

Past rockfall locations in the Valley can be identified by deposited blocks and scarps at the cliff faces. In this study we found 37 rockfall blocks throughout the study area with a median volume of $1.3 \mathrm{~m}^{3}$ (Table 2). The blocks can be classified as slightly to moderately weathered (ISRM 1981), ranging in size from large to very large (BS EN ISO 14689:2018). Most of the mapped blocks are in the eastern part of the research site, near the tombs KV19, KV20, and KV43 (Fig. 6a,b), and in the North, in the gully $g 1$ below the cliff segments $\mathrm{C} 1$ and $\mathrm{C} 2$, near the tomb entrance of KV1 (Fig. 4). The size of sub-angular to angular blocks deposited in the gully near KV1 vary from $0.1 \mathrm{~m}^{3}$ to $1.3 \mathrm{~m}^{3}$ and most of them have a cubic shape. We believe that many past events are not preserved within the Valley due to remobilisation by flash floods and artificial clearings. However, the entrance to the Valley (Fig. 6c) and the adjacent Wadi al-Gurud (Fig. 6d) may give some insight into the possible quantity of the Valley's prehistoric rockfall debris.

The horizontal distances of the deposited blocks from the cliffs range between approximately 2 and $87 \mathrm{~m}$ (Table 2; Fig. 7), with the most distant encounters of rockfall blocks found in gullies (e.g., gully gl; Fig. 4). The four outliers on Fig. 7, which travelled between 76 and $87 \mathrm{~m}$, were likely remobilised along the gully $g l$ by flash floods. These events were excluded from the shadow angle analysis. The rockfall volumes range from 0.1 to $9 \mathrm{~m}^{3}$. The largest deposited rockfall material was found near the tomb entrance of KV43 underneath $\mathrm{C} 18$, with eleven large-sized $\left(\sim 0.5-9 \mathrm{~m}^{3}\right)$ blocks on top of a debris layer with angular limestone and light-coloured flint fragments. In addition, near the entrances of KV19 and KV20, there are three deposited blocks of a similar size as the blocks found near KV43. About $16 \%$ of the identified rockfall blocks are of massive marly limestones and are located mostly near the cliffs with an average horizontal distance of $11 \mathrm{~m}$ to the cliffs and release areas, respectively. The remaining about $84 \%$ of blocks belong to the irregularly 
Table 2 Rockfall blocks identified at the study site of the Kings' Valley

\begin{tabular}{|c|c|c|c|}
\hline Rock mass type & Cliff segment & $\begin{array}{l}\text { Horizontal } \\
\text { distance from the } \\
\text { cliff }(m)\end{array}$ & Volume $\left(\mathrm{m}^{3}\right)$ \\
\hline $1 *$ & $\mathrm{C} 1$ & 22.0 & 0.11 \\
\hline $2 * *$ & $\mathrm{C} 1$ & 25.0 & 0.16 \\
\hline 2 & $\mathrm{C} 1$ & 22.0 & 0.21 \\
\hline 1 & $\mathrm{C} 1$ & 2.0 & 0.05 \\
\hline 2 & $\mathrm{C} 1$ & 34.0 & 0.58 \\
\hline 2 & $\mathrm{C} 1$ & 76.0 & 1.31 \\
\hline 2 & $\mathrm{C} 1$ & 80.0 & 0.48 \\
\hline 2 & $\mathrm{C} 1$ & 86.0 & 0.19 \\
\hline 2 & $\mathrm{C} 1$ & 87.0 & 0.17 \\
\hline 1 & $\mathrm{C} 1$ & 19.0 & 0.78 \\
\hline 1 & $\mathrm{C} 1$ & 6.0 & 0.36 \\
\hline 1 & $\mathrm{C} 3$ & 1.5 & 4.78 \\
\hline 1 & C6 & 15.0 & 1.46 \\
\hline 2 & $\mathrm{C} 16$ & 20.5 & 1.51 \\
\hline 2 & C16 & 20.3 & 1.50 \\
\hline 2 & $\mathrm{C} 16$ & 33.0 & 1.70 \\
\hline 2 & $\mathrm{C} 18$ & 15.0 & 4.56 \\
\hline 2 & $\mathrm{C} 18$ & 26.0 & 2.41 \\
\hline 2 & C18 & 29.0 & 1.06 \\
\hline 2 & C18 & 41.0 & 5.34 \\
\hline $3 * * *$ & C18 & 42.0 & 6.72 \\
\hline 2 & $\mathrm{C} 18$ & 36.0 & 0.47 \\
\hline 2 & C18 & 18.0 & 3.89 \\
\hline 2 & $\mathrm{C} 18$ & 23.0 & 7.70 \\
\hline 2 & $\mathrm{C} 18$ & 13.0 & 9.06 \\
\hline 2 & $\mathrm{C} 18$ & 4.5 & 0.97 \\
\hline 2 & $\mathrm{C} 18$ & 6.0 & 4.15 \\
\hline 2 & C19 & 4.0 & 2.72 \\
\hline 2 & $\mathrm{C} 20$ & 20.0 & 1.13 \\
\hline 2 & $\mathrm{C} 20$ & 8.0 & 3.26 \\
\hline 2 & $\mathrm{C} 21$ & 10.2 & 1.38 \\
\hline 2 & $\mathrm{C} 21$ & 10.0 & 1.91 \\
\hline 2 & $\mathrm{C} 21$ & 37.0 & 0.65 \\
\hline 2 & $\mathrm{C} 21$ & 25.0 & 0.51 \\
\hline 2 & $\mathrm{C} 21$ & 23.5 & 1.43 \\
\hline 2 & $\mathrm{C} 21$ & 21.0 & 0.42 \\
\hline \multirow[t]{4}{*}{2} & $\mathrm{C} 21$ & 11.0 & 0.33 \\
\hline & Minimum value & 1.50 & 0.05 \\
\hline & Maximum value & 87.0 & 9.06 \\
\hline & Median value & 21.0 & 1.31 \\
\hline
\end{tabular}

* Massive marly limestone

** Irregularly bedded (and nodular) limestone

*** Thebes unit younger than Thebes 1 sequence 

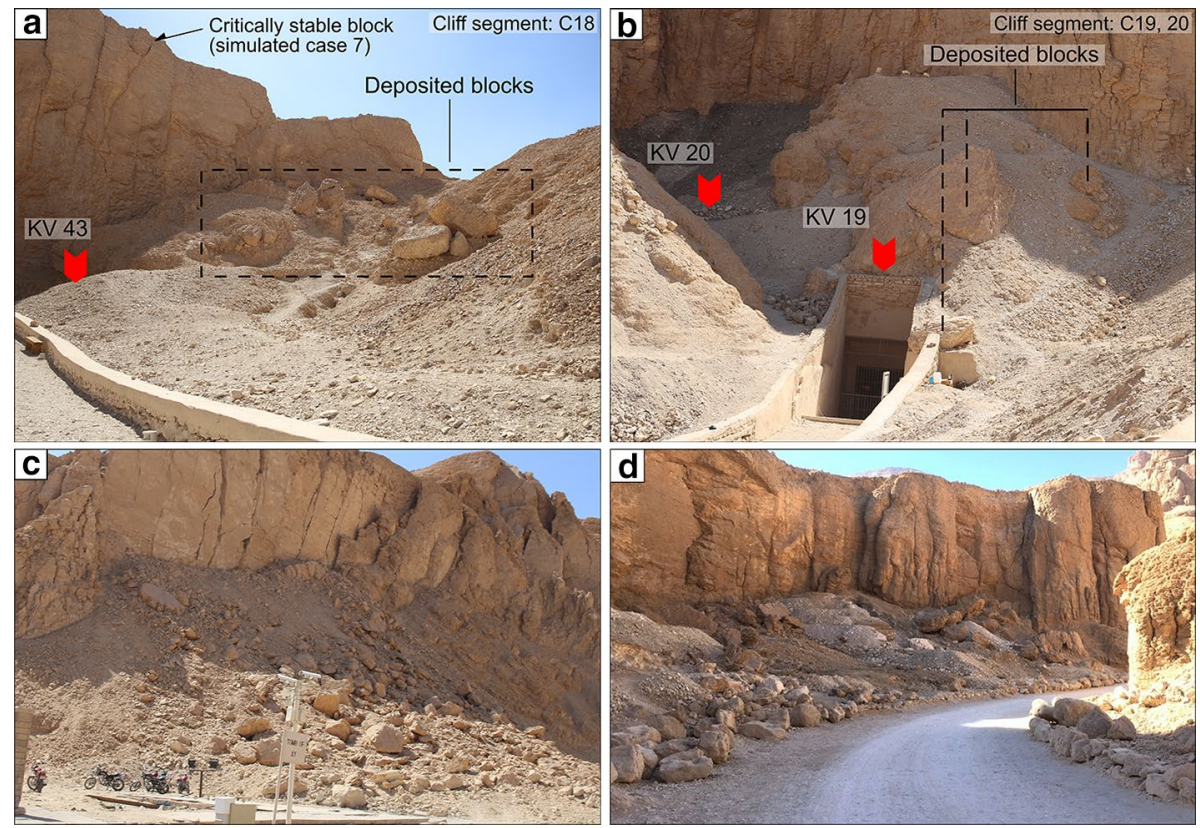

Fig. 6 a Preserved past rockfall events near KV43 and b near KV20 and KV19. $\mathbf{c}$ Well preserved rockfall debris at the entrance of the Kings' Valley and (d) in the Western Valley (Wadi el-Gurud)

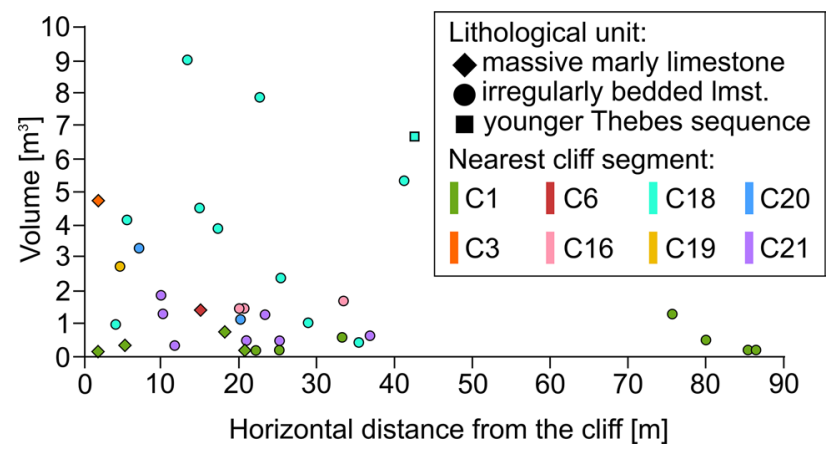

Fig. 7 Volume versus horizontal distance from nearby cliff segments of mapped blocks, together with block lithology

bedded nodular limestone, including a block from a unit younger than Thebes 1 sequence (found only near KV43; Fig. 7). These blocks have an average horizontal distance of $29 \mathrm{~m}$ from the closest cliff.

In total, 44 potential past rockfall scarps were identified and measured at the 23 cliff segments, using a threshold estimated minimum volume of $0.156 \mathrm{~m}^{3}$ (Table 3). The median height of mapped scarps above ground is $12 \mathrm{~m}$ and the maximum height is $31 \mathrm{~m}$ (C18). The maximum estimated scarp volume of $\sim 9.3 \mathrm{~m}^{3}$ was found on cliff segment $\mathrm{C} 4$ with a scarp height of $19.2 \mathrm{~m}$. No associated rockfall deposits were found, likely because 
Table 3 Rockfall scarps identified in the massive marly limestone
Cliff segment

Height above adjacent ground (m)

Volume

estimate

$\left(\mathrm{m}^{3}\right)$

$\mathrm{C} 1$
$\mathrm{C} 1$
$\mathrm{C} 1$
$\mathrm{C} 4$

C4

C4

C6

C7

C7

C7

C8

C8

C8

C9

C10

C10

C11

C12

C12

C14

C14

C14

C14

C14

C14

C15

C15

C15

C15

C15

C18

C18

C18

C19

C19

C20

C20

$\mathrm{C} 20$

$\mathrm{C} 20$

C20

C20

C21

$\mathrm{C} 22$

C23
2.6

3.5

1.89

0.42

5.6

1.27

1.71

0.78

12.0

9.26

0.92

0.61

0.35

9.20

2.18

1.15

0.83

2.32

0.87

3.13

0.80

0.60

1.52

1.23

0.54

0.40

0.21

0.72

0.79

0.29

0.27

0.87

1.83

0.40

2.91

2.42

0.99

2.46

2.35

1.60

2.28

1.06

0.84

1.91

0.90

1.21

2.35

1.61 
Table 3 (continued)

\begin{tabular}{lll}
\hline Cliff segment & $\begin{array}{l}\text { Height above adjacent } \\
\text { ground }(\mathrm{m})\end{array}$ & $\begin{array}{l}\text { Volume } \\
\text { estimate } \\
\left(\mathrm{m}^{3}\right)\end{array}$ \\
\hline Minimum value & 2.0 & 0.21 \\
Maximum value & 31.0 & 9.26 \\
Median value & 12.0 & 1.11 \\
\hline
\end{tabular}

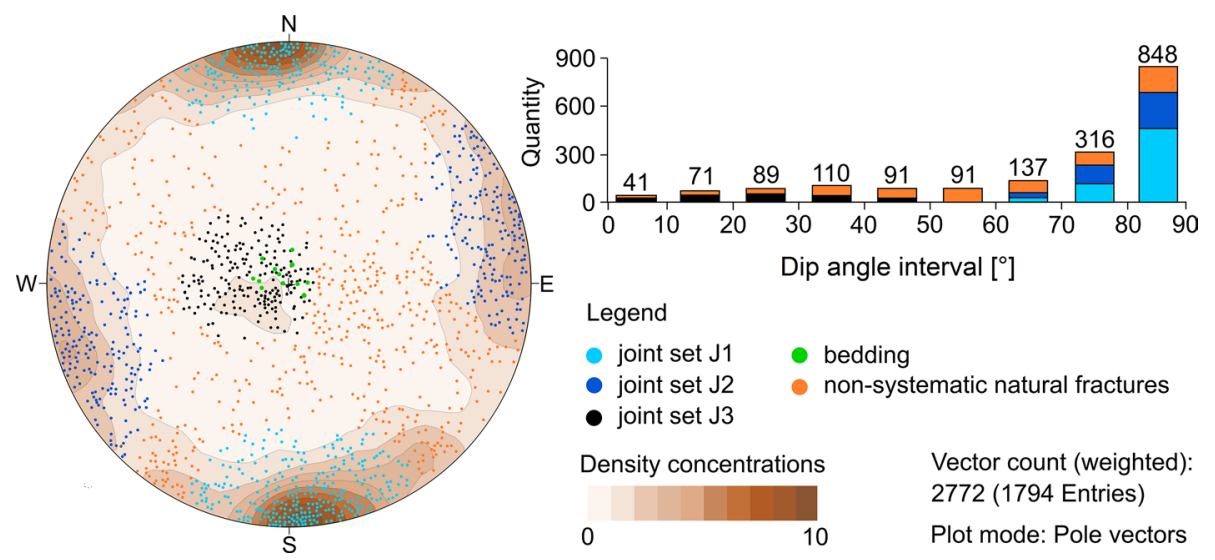

Fig. 8 Pole points to 1794 joint planes with density contouring using Terzaghi weighting. Major joint sets $\mathrm{J} 1$ and $\mathrm{J} 2$ are subvertical, strike $\mathrm{N}-\mathrm{S}$ and $\mathrm{W}-\mathrm{E}$, while the minor joint set $\mathrm{J} 3$ is subparallel to the bedding direction, with a range of dip angles from sub-horizontal to gently inclined $\left(0^{\circ}-30^{\circ}\right)$

of excavation activities. Most scarps showed steep N-S and W-E striking joints and open, weathered (i.e., mechanically weakened) joints along the subhorizontal bedding. The identified rockfall scarps are located mostly in massive marly limestone. No spatial clustering of rockfall source areas was identified.

\subsection{Rock mass discontinuities}

Some of the most prominent fractures are listric and other normal faults, which cut massive marly and irregularly bedded limestones. Listric faults occur along cliff segments $\mathrm{C} 1$, and C5-7 and cut these cliffs at their top with dip angles as steep as $\sim 45^{\circ}$ and dip directions towards E-SE. In addition, planar normal faults are common in the northern $(\mathrm{C} 1, \mathrm{C} 2$, C5) and southern part (C7, C11, C15) of the research area and strike N-S to NNE-SSW and NW-SE (Fig. 4). The first set can be associated to the Kings' Valley graben structure (Sect. 2) that may have led to the measured altitude difference of 20-30 m in the cliff tops between south-eastern (higher altitude) and northern to south-western cliffs (lower altitude) as seen in (Fig. 3c).

Our analysis identified two frequent tectonic joint sets as seen in Fig. 8, similar to those of previous authors (e.g., Wüst 1995). The first set $(\mathrm{J} 1 ; N=617)$ has an orientation of $355 / 88 \pm 17^{\circ}$ (average dip direction/dip angle and one standard deviation). The second set's orientation is $076 / 89 \pm 19^{\circ}(\mathrm{J} 2 ; N=383)$. The joint persistence of sets 1 and 2 are on the order of many tens of metres, usually cutting through the entire Thebes 1 sequence or 
at least its lower portions. Additionally, we identified a minor joint set (J3; N=223) of sub-horizontal joints with mean orientation of $100 / 20 \pm 21^{\circ}$, with a maximum persistence of a few metres (cf., Pawlikovski and Wasilewski 2004). It is of interest to note that 29\% $(N=571)$ of the discontinuities seemed non-systematic. These latter fractures have a very wide range of orientations and moderately steep to vertical dip angles (30-90 $) .73 \%$ of the 1794 measured discontinuities dip steeper than $60^{\circ}$, most of which fall even within the range of $80^{\circ}-90^{\circ}$. The remaining $27 \%$ of fractures are about equally distributed in the $10^{\circ}$ intervals between $0^{\circ}$ and $60^{\circ}$ (Fig. 8). Finally, rock bedding orientations are mostly subhorizontal to slightly dipping $\left(\sim 15^{\circ}\right)$, except for rock masses affected by listric faulting where bedding dip can be as steep as $30^{\circ}$ (few measurements, not included in Fig. 8). Cliff segments of groups I and II (Table 1) follow the steep, N-S and W-E striking tectonic joint sets. In contrast, the cliffs belonging to group III and IV do not follow the orientation of the main tectonic sets and strike NW-SE (C11) and NE-SW (e.g., C17-21), respectively. At places, the general orientations of latter cliff segments are at an angle to the inherent, smaller scale tectonic joint planes.

The true spacing of the joint sets are smaller in the lowermost unit of the massive marly limestone (on the order of $\mathrm{dm}$ ) compared to its higher portions, where the true spacing ranges from dm to many metres. Finally, the irregularly bedded (nodular) limestone comprised the least frequent joint spacings but upon weathering disintegrates into small, dmsized components and blocks that are frequently bound by non-systematic joints (and tension cracks) of few metres in length.

\subsection{Potential new rockfall source areas and release mechanisms}

Potential rockfall source areas were recognised along the subvertical cliffs of the inner valley. It should be noted that we focused on identifying potentially unstable zones and their release mechanism in areas near public walking paths, tomb entrances, and active excavation areas. Thus, our list of potential source areas is not complete. Most of the potential instabilities were found on the very top of the cliffs, in the irregularly bedded to nodular limestone. We show our selection of nine critical areas in Fig. 9a-i, corresponding to the simulated cases 1-9. Potential source areas are characterised by (i) weathered portions of the cliff that developed a block of significant size ( $>0.5 \mathrm{~m}$ edge length), bound by tectonic joints, bedding planes and frequent $\mathrm{cm}-\mathrm{dm}$ open tension cracks (Fig. 9a,b,d-h), or (ii) laterally unconstrained blocks that rest on inclined fault or joint planes (Fig. 9c,i). Considering the latter two cases, widely detached very large blocks (BS EN ISO 14689, 2018) of $\sim 6.7 \mathrm{~m}^{3}$ and $\sim 9 \mathrm{~m}^{3}$ rest on fault planes with a dip angle of about $30^{\circ}$, located above currently active excavation areas. Except for the lower portion of the block in case 3 at $\mathrm{C} 7$, which is made of massive marly limestone, the critical areas of the displayed cases all lie in irregularly bedded limestone.

To understand the general failure kinematics of rock blocks exposed at the 23 cliffs, we calculated the failure probabilities of planar sliding, wedge sliding, and toppling (Fig. 10). Furthermore, these cliffs were organised into four groups, depending on their strike direction (Table 1). Planar sliding is common within massive marly limestone and irregularly bedded nodular limestone, where large structural features such as listric and other normal faults cut cliff walls. Sliding blocks are formed by a combination of intersecting systematic (J1-J3, J5) and/or non-systematic joints that terminate at, or intersect the basal sliding plane (i.e., fault or joint plane), e.g., at cliff segments C11 near KV32 (Fig. 11a). On the cliffs of group I (N-S trending), planar sliding occurs along J2 (except for C2), while for 

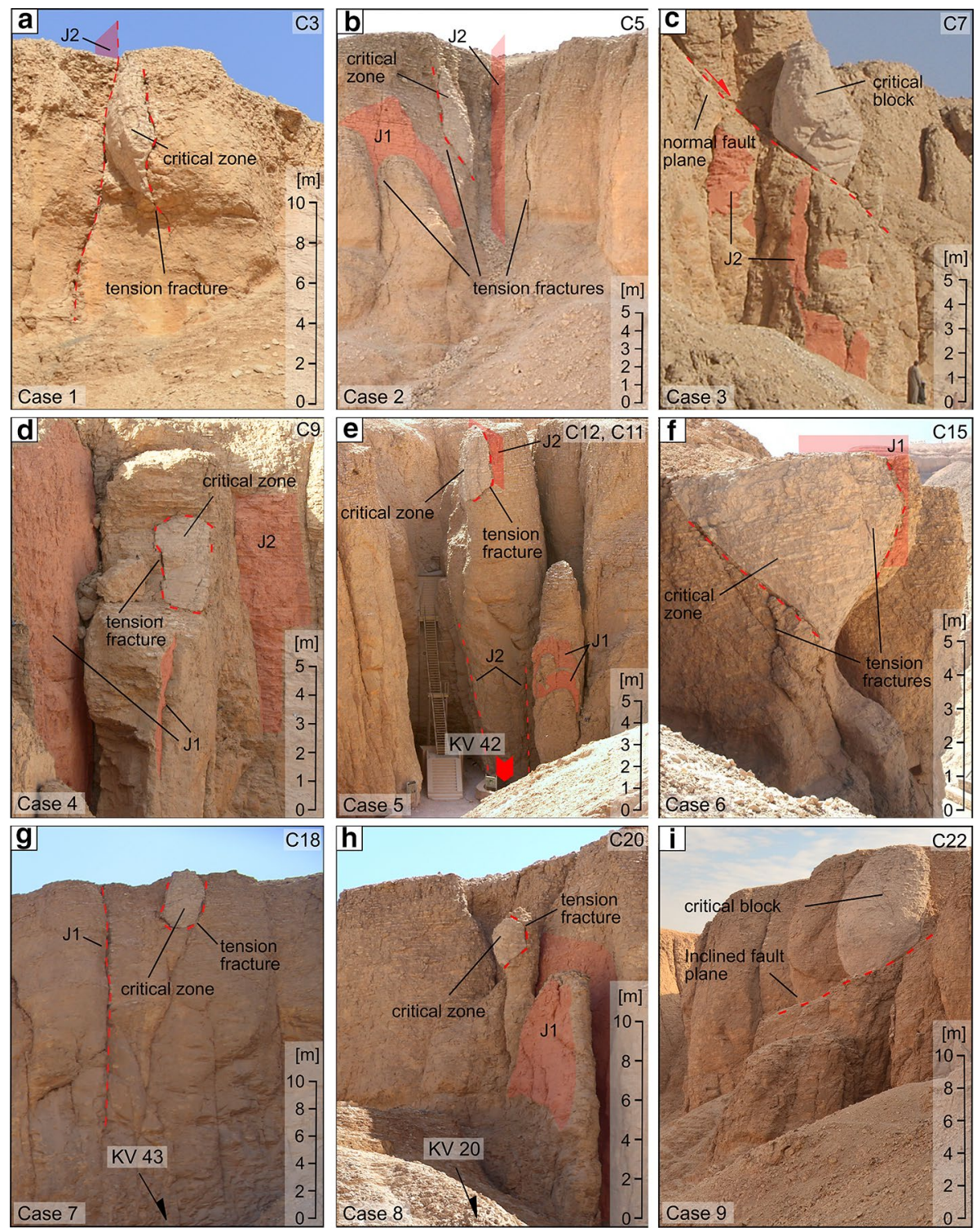

Fig. 9 a-i Examples of release zones of possible rockfalls that were selected for instability simulations 1-9. The critical rock masses (zones), some of which are single blocks, are mostly located in the irregularly bedded (nodular) limestone. Given scales are rough estimates for the size of the cliffs in the figure backgrounds

group II cliffs (W-E trending), planar sliding is along the joint set J1. The probability of sliding is similar for most of the cliff segments, except for $\mathrm{C} 2, \mathrm{C} 12$, and C6. Low probabilities for planar sliding occur where main joint sets striking about parallel to the cliff, e.g., J2 at $\mathrm{C} 12$ (overhanging cliff portion, Fig. 3c), dip into the slope. The highest probabilities of planar sliding (>20\%; Fig. 10a) were found in the NW part of the Valley (e.g., C4) and in its southern parts (e.g., C10 and C15). 


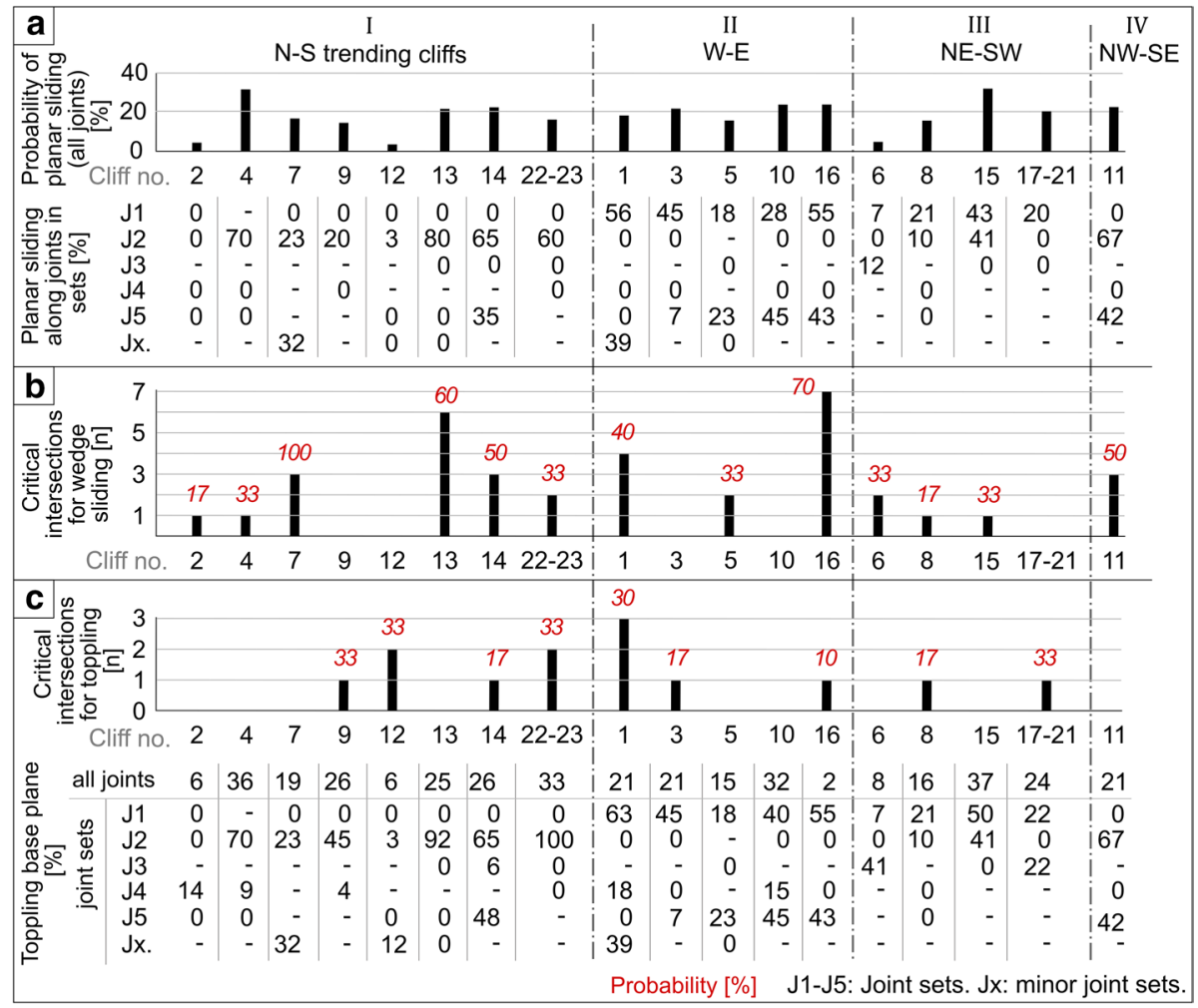

Fig. 10 Kinematic analysis for three failure modes: a planar sliding, b wedge sliding, and $\mathbf{c}$ toppling along 23 cliff segments (for location see Fig. 3). The histograms show the probabilities of the failure modes per cliff segment that we grouped into four orientation (trend) classes. Probability is defined here as the percentage of all critical joints for planar sliding failure, percentage of mean joint set combinations for wedge failure, and percentage of mean joint set plane intersections for toppling failure. $\mathbf{b}$, $\mathbf{c}$ Probability values are given together with the number of critical intersections in (b) and (c). The values in tables present the probability values (i.e., percentage of joints in sets) contributing to a planar sliding and $\mathbf{c}$ forming base planes required for toppling failure

The wedge sliding probability was analysed only for defined joint sets of each cliff segment. The estimated probabilities of wedge sliding range from $0-100 \%$ (with $0 \%$ for cliffs C3, C9 C10, C12 and C17-21, and 100\% for C7). The probability values are strongly influenced by the number of joint sets and their intersections identified at a cliff segment, i.e., cliffs with more critical intersections can show lower failure probability than others and vice versa (e.g., cliff segment $\mathrm{C} 7$ has three joint sets and three critical intersections leading to $100 \%$ probability while $\mathrm{C} 13$ has six critical intersections of five joint sets and, thus, a $60 \%$ probability; Fig. 10b; Table 1). Cliffs with critical intersections belong to the group I (C2, C4, C7, C13, C14, C22-23), group II (C1, C5, C16), group III (C6, C8, C15) and group IV (C11). Wedge sliding is most likely to occur in the massive marly limestone (see, e.g., scarps on $\mathrm{C} 1$ and C8; Fig. 11b,c). Of particular interest are rock wedges present in overhanging cliff portions (Fig. 11c,f), which would likely fall freely if detached.

Toppling is controlled by the presence of subvertical joint sets $\mathrm{J} 1$, J2, and J5 (Fig. 10c), parallel to the cliff's face. Critical intersections prone to direct toppling can be found at cliffs from group I (C9, C12, C14, C22-23), group II (C1, C3, C16) and 

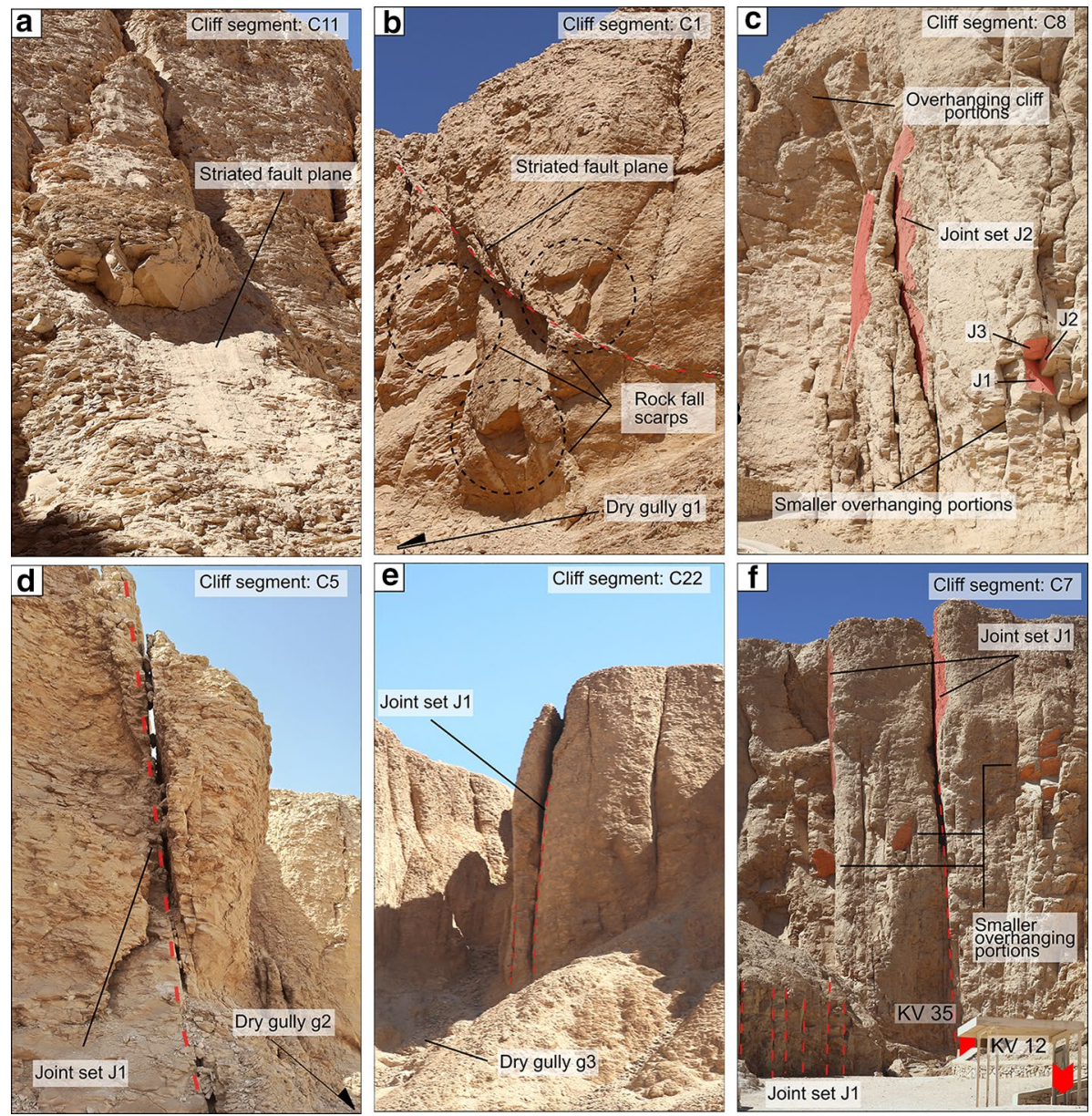

Fig. 11 a Planar sliding is a potential release mechanism on $\mathrm{C} 11$, where some rock mass portion is resting on a striated fault plane. b C1 is one of many cliff segments that contain sharp rockfall scarps in massive marly limestone. c Overhanding cliff portions on C8. d critical rock mass with an erosional notch at the cliff's toe prone to toppling. Prominent, cm-dm open tension cracks follow joint set J1 at the cliff segment $\mathrm{C} 5$ and e $\mathrm{C} 22$. f Widely open, subvertical fractures belonging to joint set J1 on cliff C7

group III (C8, C17-21). Cliffs of group I strike parallel to the joint set J2 and therefore this joint set controls toppling in N-S trending cliffs (e.g., cliff 12 close to KV42 with 33\% toppling probability; Fig. 9e). Similarly, toppling along group II cliffs is controlled by the slope parallel joint set $\mathrm{J} 1$ and is especially pronounced for $\mathrm{C} 1$. However, 9 out of 23 cliff segments have no critical joint set intersections forming blocks prone to topple, despite a good portion of up to $37 \%$ of joints forming potential basal planes necessary for toppling (Fig. 10c). A representative example of a cliff segment with zero toppling probability, despite its orientation, is C5 (group II; Fig. 9b) that hosts a steep, prominent fracture with an open aperture of dm-size at $\mathrm{C} 5$, belonging to set $\mathrm{J} 1$. The fracture shapes a potentially critical rock column that may fail through planar or wedge sliding rather than toppling (Fig. 11d). The spacing of cliff-parallel joints (J1 and J2) vary between few dm to several metres and the joint apertures near the cliff 
faces range from few $\mathrm{cm}$ (e.g., at cliff segments $\mathrm{C} 5$ and $\mathrm{C} 10)$ to tens of centimetres (e.g., at C8, C22, and C23) (Fig. 11c-f).

In summary, all mapped cliffs, have a probability of at least one kinematic mode occurring, and many have multiple potential failure modes with significant probabilities. Cliffs C7-C15 and C18-20 are located adjacent to tomb entrances and foot paths. Thus, if the assumptions of the kinematic analysis can be confirmed, rockfall susceptibility is noteworthy in some critical locations in the Valley. The most critical assumption of the present analysis is that fractures are fully persistent. In reality, critical blocks are likely held in place by rock bridges (see Figs. 6a and 9), however these rock bridges may degrade through time. This is discussed further in Sect. 5.2.

\subsection{Rockfall runout map}

The rockfall runout map of Fig. 12 displays the projected shadow angle of $35^{\circ}$ and the numerical simulation results of nine potential rockfall events presented in Fig. 9. The geometric properties of the nine case study blocks and the surface properties of the transit zones used in the simulation are listed in Table 4. Note that the presented numerical simulation results of Fig. 12 display the reach probability range from 0 to $100 \%$ of each event. Based on comparison of all simulated shadow angles $\left(27^{\circ}-37^{\circ}\right.$; Sect. 3.4) with our site investigations, a shadow angle of $35^{\circ}$ was found to be the best estimate, i.e., all mapped rockfall blocks lie within the projected boundary. As mentioned previously, the four blocks located outside the projected shadow angle, northeast of KV1 (Fig. 12), were likely remobilised by flash flooding and so were excluded from the assessment. A decrease of the shadow angle below $35^{\circ}$ overestimated runout distances from mapped, past rockfall debris. In addition, a shadow angle of $35^{\circ}$ is supported by the nine simulations located on the cliffs C3, C5, C10, C11, C15, C18, C20, and $\mathrm{C} 22$. All simulated rockfall trajectories did not cross the projected shadow angle and remained inside the estimated reach probability (Fig. 12).

About $26 \%$ of the public walking path area locates within the extent of the estimated runout propagation zones (Fig. 12). Furthermore, 24 out of 64 tomb entrances with adjacent waiting areas are within the projected runout boundaries, of which 14 are within $10 \mathrm{~m}$ distance from a cliff. The remaining 10 tomb entrances are located at the foot of hill slopes. Cliff heights above critical tomb entrances range from $8 \mathrm{~m}$ above KV34 (cliff segments C12 and C13) to 43 m above KV20 (cliff segment C20), with a median height of $30 \mathrm{~m}$.

Deposited rockfall material of past events were found only near the tombs KV19, 20 and 43 (Fig. 12). Considering cliff heights and block volumes (the median volume of mapped blocks is $1.3 \mathrm{~m}^{3}$ ), the mean intensity of our nine simulated cases range between 625 and $3500 \mathrm{~kJ}$, with the total average value of $2100 \mathrm{~kJ}$. Thus, these cases fall within the $>300 \mathrm{~kJ}$ category of the Swiss rockfall hazard estimation (FOEN 2016), i.e., classifying as 'high risk' zone even for long return periods ( $>100$ years). 


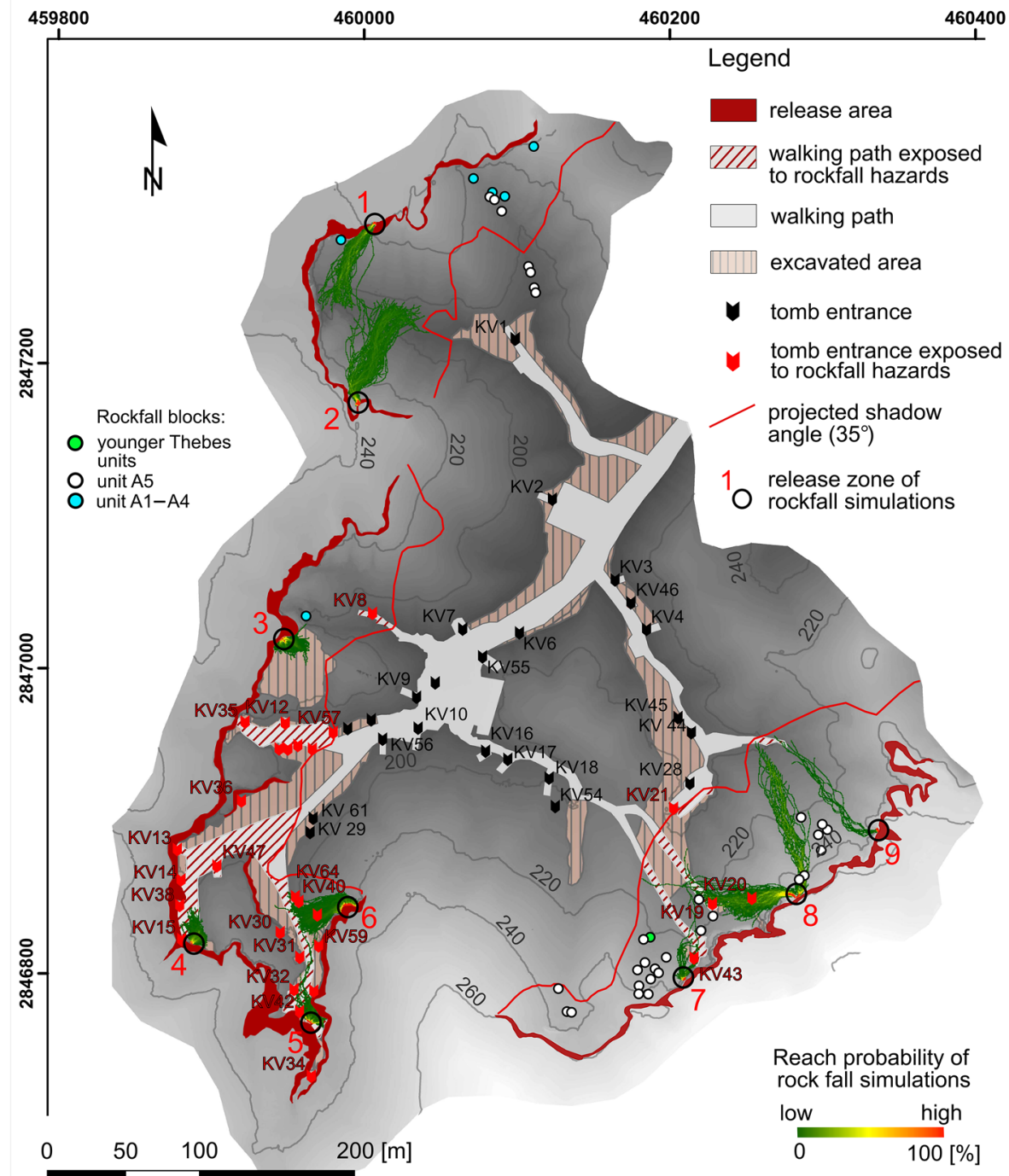

Fig. 12 Map of the projected rut-out probabilities of nine simulations labelled 1-9, together with the most probable shadow angle. The map highlights the parts of the public walking paths (red stripes) and 24 tomb entrance areas (red arrows) that lie within the projected runout boundaries of the release zones (marked in red)

\section{Discussion}

\subsection{Past rockfalls}

Previously, no database of rockfalls existed for the Kings' Valley. Potential past rockfall release zones along the inner valley cliffs and deposited blocks were obtained by field and digital mapping using a new DEM calculated from TLS surveys. We identified 44 
Table 4 Input parameter (ranges) for rockfall simulation cases (1-9) using Rockyfor3D based on field mapping and the catalogue values provided by Dorren (2016)

\begin{tabular}{|c|c|c|c|c|c|c|c|c|}
\hline \multirow[t]{3}{*}{ Case } & \multicolumn{3}{|c|}{ Transit zone } & \multicolumn{5}{|l|}{ Release zone } \\
\hline & \multicolumn{2}{|c|}{$\begin{array}{l}\text { Surface rough- } \\
\text { ness } \\
\text { rg10-rg70 (m) }\end{array}$} & \multirow[t]{2}{*}{$\begin{array}{l}\text { Surface cover / } \\
\text { soil type* }\end{array}$} & \multirow[t]{2}{*}{ Block shape** } & \multirow[b]{2}{*}{$\mathrm{d} 1$} & \multicolumn{2}{|l|}{$\begin{array}{l}\text { Size } \\
(\mathrm{m})\end{array}$} & \multirow[t]{2}{*}{$\begin{array}{l}\text { Density } \\
\left(\mathrm{kg} / \mathrm{m}^{3}\right)\end{array}$} \\
\hline & $\min$ & $\max$ & & & & $\mathrm{d} 2$ & $\mathrm{~d} 3$ & \\
\hline 1 & 0.03 & 0.45 & $3-6$ & 1 & 4.40 & 1.80 & 0.60 & \\
\hline 2 & 0.05 & 0.40 & $3-6$ & 1 & 2.10 & 1.40 & 0.60 & \\
\hline 3 & 0.01 & 0.15 & $3-6$ & 2 & 4.00 & 2.10 & 1.10 & \\
\hline 4 & 0.03 & 0.40 & $3-6$ & 4 & 2.50 & 1.40 & 0.85 & \\
\hline 5 & 0.01 & 0.25 & $3-6$ & 1 & 3.20 & 3.10 & 1.30 & 2550 \\
\hline 6 & 0.04 & 0.45 & $2-6$ & 2 & 3.60 & 2.60 & 2.10 & \\
\hline 7 & 0.01 & 0.60 & $3-6$ & 3 & 2.70 & 2.10 & 1.70 & \\
\hline 8 & 0.01 & 0.35 & $3-5$ & 1 & 1.70 & 1.60 & 0.80 & \\
\hline 9 & 0.02 & 0.55 & $3-5$ & 2 & 6.80 & 4.10 & 1.25 & \\
\hline
\end{tabular}

*(2) sand/gravel, (3) scree/soil with small rock fragments, (4) talus slope/soil with large rock fragments, (5) bedrock with soil cover, (6) bedrock

** (1) rectangular, (2) ellipsoidal, (3) spheric, (4) disced

possible past rockfall scarps. This number is likely underestimated, as we limited our search on detached rock volumes greater than $0.156 \mathrm{~m}^{3}$ and unweathered scarps with distinct fractures (planes of joints, fault, or tension cracks; Sect. 3.3). Considering the two major rock types, massive marly limestone and irregularly bedded to nodular limestone, clear rockfall scarps were mostly identified in the massive limestone due to its distinct fracture planes. Scarps in the irregularly bedded (nodular) limestone are much more difficult to identify and to measure. The bedded rock mass is cut by fewer planar joint planes (Sect. 4.3) and tension cracks formed in this rock mass have very rough surfaces that can be difficult to distinguish from physically weathered rock surfaces and rock disintegration into rock nodules (Ziegler et al. 2019). Thus, we likely underestimated rockfall source areas in the irregularly bedded limestone.

Nevertheless, the large number of possible rockfall source locations contrasts considerably with the small number of mapped rockfall debris, suggesting that excavation activities over about two centuries (e.g., Reeves and Wilkinson 1996), the building of tourist infrastructure (Fig. 4), as well as remobilisation of rockfall material during flash floods (e.g., Cross 2008) substantially reduced rockfall deposits in the Kings' Valley. Most of the mapped blocks have angular shapes to slightly rounded edges and corners indicating short transport distances (maximum tens of $\mathrm{m}$ ) and/or high durability, which agrees well with high slake durability index of the marly limestones of the Valley as identified by Alcaíno-Olivares (pers. comm.). Mapped rockfall blocks ranged from 0.05 $\mathrm{m}^{3}$ to $9 \mathrm{~m}^{3}$ with a median size of $1.3 \mathrm{~m}^{3}$. Assuming a (unknown but likely) low activity (return period of 100-300 years) and typical fall heights of 10-30 m such blocks would classify as moderate to high risk according to the Swiss rockfall classifications (FOEN 2016; Jaboyedoff et al. 2005). Note that an estimation of the return period is not possible due to the lack of significant recordings of past rockfall events. 
Blocks of massive marly limestone of unit A were found within about $20 \mathrm{~m}$ of the nearest cliff, while most material belonging to the irregularly bedded limestone (unit A5) were found as far away as about $40 \mathrm{~m}$ from the nearest cliff (Fig. 7). This observation can be explained by the shadow angle concept suggesting increasing rockfall travel distances for source regions of higher altitude, i.e., the latter rockfall blocks have greater potential and thus kinetic energy and can travel further away from the cliff faces. Four blocks of irregularly bedded limestone with volumes of $0.17-1.31 \mathrm{~m}^{3}$ were found in gully $\mathrm{g} 1,76-87 \mathrm{~m}$ away from the cliff segment $\mathrm{C} 1$. We argue that these blocks originated as rockfalls but were likely remobilised in later debris flow(s).

We have estimated a shadow angle of $35^{\circ}$ based on the maximum extent of mapped past rockfall events. An angle of $35^{\circ}$ is within but at the upper end of literature value ranges of typically $22^{\circ}-37^{\circ}$ (Jaboyedoff and Labiouse 2011). Since rockfall deposits were only identified outside areas of walking paths it is possible that the estimated angle is too high and does not enclose all former (and possible future) rockfall events (cf., Sect. 5.2). In addition, this single value is likely not representative for all past rockfalls because of the small number of known rockfall deposits and the heterogeneity of the ground's morphology.

\subsection{Susceptibility of future rockfalls}

Structural analysis of the Valley shows that many cliff segments roughly follow the orientation of one of the two main joint sets, which strike N-S and W-E (Table 1; Fig. 8). At places, the combination of the two sets leads to cliff segments with overall strike orientation at an angle to the major joint planes. Such cliffs have overall strike directions of NE-SW and NW-SE. The orientation of the cliffs impacts the type of release mechanism. Cliffs in groups I and II that are oriented parallel to the W-E and N-S striking joint sets, are prone to toppling and some exhibit critically stable blocks (e.g., C1, C12, C16, as well as between $\mathrm{C} 22$ and $\mathrm{C} 23$ at gully $\mathrm{g} 3$ ) that have fracture apertures ranging from $\mathrm{cm}-\mathrm{dm}$. Further, we found that planar sliding is mostly restricted to larger tectonic fault planes (Fig. 11a,b) that act as basal sliding surfaces. At places, slides may develop where the rock mass is destabilised by the development of tension cracks (Fig. 9a,b,g,h). It should be noted that sliding planes in the layered units may be very rough and stepped, leading to larger friction angles of the developing basal sliding surfaces greater than our assumed friction angle of $25^{\circ}$. Cliffs prone to wedge sliding were identified along the Valley and our kinematic analysis suggests that 14 out of 23 cliff segments have at least one critical intersection of the main joint sets (Fig. 10b). The main joint sets are approximately subvertical and normal to each other, i.e., rock prisms formed by intersection lines do not daylight at the cliff walls. Thus, wedge formation may be limited to where inclined normal faults and/ or unsystematic, less steeply dipping joint sets intersect each other. However, overhanging cliff segments can host rock wedges that may be released (freely fall) when cut by weakened bedding discontinuities, subhorizontal fractures of set J3, or non-systematic fractures (Fig. 11c,f).

To better estimate the possible spatial extents and energies of potential rockfall events we selected nine possible release zones (Fig. 9). These zones are mostly located in the irregularly bedded limestone. The calculated intensities of all nine rockfall simulations were greater than $300 \mathrm{~kJ}$, suggesting high hazard zones, independent of the return period, so long as it is less than 300 years (FOEN 2016). This is concerning, as zones impacted by these 'high hazard' events are visited by several thousands of tourists at each day of the week. All simulated rockfall trajectories located within the area are enclosed by our shadow angle of $35^{\circ}$, suggesting 
that it might be a good estimate considering the lack of past data. It also seemed conservative as only simulated rockfalls with a low probability reached close to the boundary as displayed in Fig. 12 (cases 2, 8, and 9) and some trajectories are considerably far away from it (e.g., cases $1,3,4$, and 7). The latter may be explained, at least partly, by our use of the cliff tops as source regions for rockfalls instead of source areas at lower parts of a cliff (Sect. 3.4). Rockfalls originating from lower heights would travel less far.

Boulders, scree, and disintegrated irregularly bedded to nodular limestone were found on top of the cliffs, near their edges (Figs. 4, 5e). Thus, the projected shadow angle was calculated along the entire cliff top with the intention to include and predict potential runout zones of such materials (Fig. 12). They present another potential hazard when mobilised, such as by flooding or weakened by physical weathering in case of the irregularly bedded or nodular limestone. At places, such as the visitor stairways to KV34, where the public path is adjacent to cliffs, mobilisation of even small rocks can be hazardous.

Possible triggering mechanisms can include, heavy rainfall, earthquakes, and more recently observed thermal forcing (Collins and Stock, 2016). Rainfall seldom occurs, however, flash flooding caused by torrential rain does occur periodically ( 10-year period) in the Theban Necropolis (Guillaume et al. 1995; Leblanc 1995; Baldi 2015). It can be particularly devastating because it can cause long-term damage, such as cracking of the rock (Rutherford and Ryan 1995; Evrard and Guillaume 1997; McLane et al. 2003; Guillaume et al. 2001; Guillaume 2001-2002, 2004) partly due to swelling (Alcaíno-Olivares et al. 2019; Rutherford and Ryan 1995; Romer 1975) and other factors that influence ongoing weathering. Rainfall events can influence the failure probability of critical zones. According to the risk assessment of flash floods in the Valley by Ogiso et al. (2017: Fig. 6), there is a tendency of decreasing rainstorm frequency but an increase in their intensity recorded during the 20th century. However, the influence of rainfalls on rockfall probability requires a more detailed investigation in the future. To date, research has focused mainly on rainfall episodes and the association with rapid material remobilization during flash flooding (e.g., Dawson 2003; Aubry et al. 2009, and references cited therein). Evidence of strong earthquakes have been identified in temples of ancient Thebes (Karakhanyan et al. 2010), however, Egypt is generally characterised by low seismicity (Mohamed et al. 2012). Although rare, large earthquakes could directly trigger rockfall. However, even lower magnitude vibrations could cause smaller scale fracture propagation. Over time, repeated rainfall events and earthquakes could contribute to weakening of rock bridges. A more recent observation is the role that thermal fluctuations could play in weathering and fracture propagation. Recent studies by Eppes and Keanini (2017) and Eppes et al. (2016) have pointed to the role of cyclic thermal loading and solar radiation on weathering processes. Such studies have prompted researchers to investigate the role of temperature and other climate fluctuations on the stability of a cliff above KV42. Large daily temperature variations of $\Delta T$ of $10-20{ }^{\circ} \mathrm{C}$ have been measured by Alcaíno-Olivares et al. $(2019,2020)$ who also measured peak crack opening apertures following peak air temperatures. The authors further suggested that thermal variations and thermal conductivity can govern the cycles of opening and closing of the fractures within the cliff. This could lead to gradual weakening of rock bridges through thermal fatigue.

\subsection{Comparison to nearby sites}

A key limitation of our analysis is that there is no information preserved that could be used to estimate the return period of rockfall events (Sect. 5.1). However, the geomorphic evolution of the Valley, in terms of rock mass wasting processes, may be inferred based 
on nearby sites. The Western Valley (Wadi el-Gurud), located next to the Kings' Valley, contains more undisturbed rock debris, some of which originated as rockfalls (Fig. 6d). This indicates that, in the Kings' Valley, past evidence of rockfall has likely been destroyed through debris remobilisation in flash floods along the defined flood paths (McLane et al. 2003) and/or artificially during intense excavation activities. Abdallah and Helal (1990) at Deir El-Bahari, near the temple of Hatshepsut, documented two rockfall events, one of which occurred in 1985, and highlighted the possibility of rockfall events from the surrounding mountain. Hazard assessment by Youssef and Maerz (2009) along the Eastern Desert Aswan-Cairo highway indicated numerous rockfalls triggered by structurally controlled failures. Thus, while direct documentation of rockfall in the Valley is lacking, nearby sites suggest that it occurs relatively frequently.

\section{Conclusion}

This study presents an attempt to estimate potential rockfall susceptibility and runout in the Valley of the Kings. We used terrestrial laser scanning to survey in $\mathrm{cm}$-resolution the inner valley's geometry, including cliff faces and possible deposition areas. The obtained digital elevation model, together with site photography and structural geological mapping, helped us to identify 44 past rockfall scarps with volumes ranging between 0.2 and $9.3 \mathrm{~m}^{3}$ and 23 deposited blocks, as well as many new potential hazardous rockfall zones and their likely release mechanisms. Our record of past events is likely not complete due to natural remobilisation (e.g., flash floods) and artificial clearings during excavation works or by construction of infrastructure. Furthermore, the lack of historic records permits no estimation of the return periods of rockfalls. These missing data are necessary to estimate hazard and risk in the Valley, and its absence could lead to substantial underestimation of the amount of past rockfall activity. Nevertheless, the mapped rockfall deposits and geological mapping of readily mobilised rock debris and weathered irregularly bedded limestone close to the cliff tops suggest that rockfall may potentially occur in the Kings' Valley. Potential runout of these events, using CONEFALL and a shadow angle of $35^{\circ}$, suggests that many tomb entrances and walking paths could be impacted. We selected nine prominent release areas for a more detailed analyses on the runout probability using Rockyfor3D numerical calculations. The simulations support the estimated shadow angle as a conservative estimate. The intensities of our cases are greater than $300 \mathrm{~kJ}$ and fall into the 'high hazard' category so long as the return period is less than 300 years according to the Swiss federal guidelines on rockfall hazard assessments. 24 out of 64 tomb entrance areas and $26 \%$ of the public walking path under investigation are located within the estimated rockfall runout boundary. To assess rockfall hazard at a particular site, e.g., within the framework of site management for archaeological excavation works or public safety, more detailed site investigations are necessary. The presented work on rockfall assessment in the Valley does not claim to be complete but may raise required awareness and initiate rockfall safety precautions.

Acknowledgements The authors are very grateful to the Minister of Tourism and Antiquities HE Dr. Khaled El-Enany, to the Secretary General of the Supreme Council of Antiquities Dr. MoustafaWaziri and the Permanent Committee of the SCA in Cairo, to Dr. Nashwa Gaber, Director of the Department of Foreign Missions, and to the members of its Luxor branch, Dr. Mohammed Yahya, General Director of the Antiquities of Upper Egypt, Mr. Ghaddafi el-Azab, General Director of Luxor, Mr. Fathy Yaseen, General Director of Western Thebes, Mr. Ali Reda, Director of the Valley of the Kings, and their staff for approving and supporting our field research in Western Thebes. Mr. Mahmoud Ibrahim kindly assisted the administrative planning of our field seasons, Raīs Abd el-Hamid Osman gave technical and logistic support in the 
field. We are very thankful to Prof. Susanne Bickel [director of the University of Basel Kings' Valley Project (https://aegyptologie.philhist.unibas.ch/en/forschung/forschungsprojekte/kings-valley-project; accessed on April 3rd, 2021)], Elina Paulin-Grothe (field director), and Dr. Andrea Loprieno-Gnirs [field director of project 'Life Histories of Theban Tombs' (https://lhtt.philhist.unibas.ch; accessed on April 3rd, 2021)] from the University of Basel, Department of Ancient Civilizations, for the hospitality, field guidance, and discussions. Prof. Bickel kindly invited us to be part of the Kings' Valley project and gave us very valuable feedback on the manuscript. Prof. Andreas Wieser, chair of the Institute of Geodesy and Photogrammetry (ETH Zurich), kindly provided us with the FARO 120 S laser scanner. In addition, we thank Rodrigo Alcaíno-Olivares who provided feedback on an earlier version of the manuscript. Funding of the University of Basel Kings' Valley Project has been provided by the Gertrud Mayer Foundation and by private sponsors. Without their support, this work would not have been possible. Finally, the Swiss National Science Foundation (SNF) is acknowledged for its generous investment in the overarching project, "Diachronic perspectives on a royal necropolis: identity, agency, and interaction" under grant number 156046.

Funding Open Access funding provided by ETH Zurich.

\section{Declarations}

Conflict of interest The authors have no conflicts of interest to declare that are relevant to the content of this article.

Open Access This article is licensed under a Creative Commons Attribution 4.0 International License, which permits use, sharing, adaptation, distribution and reproduction in any medium or format, as long as you give appropriate credit to the original author(s) and the source, provide a link to the Creative Commons licence, and indicate if changes were made. The images or other third party material in this article are included in the article's Creative Commons licence, unless indicated otherwise in a credit line to the material. If material is not included in the article's Creative Commons licence and your intended use is not permitted by statutory regulation or exceeds the permitted use, you will need to obtain permission directly from the copyright holder. To view a copy of this licence, visit http://creativecommons.org/licenses/by/4.0/.

\section{References}

Abdallah T, Helal H (1990) Risk evaluation of rock mass sliding in El-Deir El-Bahary valley, Luxor, Egypt. Bull Int Assoc Eng Geol 42(1):3-9. https://doi.org/10.1007/BF02592614

Abou El-Anwar EA, Mekky HS, Abd El Rahim SH (2018) Mineralogy, geochemistry, petrography, and depositional environment of Gebel El-Qurn, Early Eocene, West Luxor, South Egypt. Bull Natl Res Cent 42(7):16. https://doi.org/10.1186/s42269-018-0008-3

Alcaíno-Olivares R, Perras MA, Ziegler M, Maissen J (2019) Cliff stability at tomb KV42 in the Valley of the Kings, Egypt: a first approach to numerical modelling and site investigation. In: 53rd US Rock Mechanics/Geomechanics Symposium. ARMA 19-275. New York City, USA. 23-26 June 2019, pp 10

Alcaíno-Olivares R, Perras MA, Ziegler M, Leith K (2020) Thermo-mechanical cliff stability at tomb KV42 in the Valley of the Kings, Egypt. In: Workshop on World Landslide Forum. Springer, Cham 471-478

Aubry MP, Berggren WA, Dupuis C, Ghaly H, Ward D, King C, Knox ROB, Ouda K, Youssef M, Hassan WF (2009) Pharaonic necrostratigraphy: a review of geological and archaeological studies in the Theban Necropolis, Luxor, West Bank, Egypt. Terra Nova 21(4):237-256. https://doi.org/10.1111/j. 1365-3121.2009.00872.x

Aubry MP, Dupuis C, Ghaly H, King C, Knox R, Berggren WA, Karlshausen C (2011) Geological setting of the Theban necropolis: Implications for the preservation of the West Bank monuments. In: Aston D, Bader B, Gallorini C, Nicholson P, Buckingham S (eds), Under the potter's tree. Studies on ancient Egypt presented to Janine Bourriau on the occasion of her 70th birthday (Orientalia Lovaniensia Analecta 204). Peeters, Leuven, pp 81-124

Aubry MP, Ouda K, Dupuis C, Berggren WA, Van Couvering JA, Ali J, Brinkhuis H, Gingerich P, Heilmann-Clausen C, Hooker J, Kent DV (2007) The Global Standard Stratotype-Section and Point (GSSP) for the base of the Eocene Series in the Dababiya section (Egypt). Episodes 30(4):271-286. https://doi.org/10.7916/D8BP0C85 
Baldi M (2015) Exceptional rainfall over Thebes in ancient and present times: an analysis of possible driving mechanisms. In: Capriotti Vittozzi G (ed) Egyptian curses 2: a research on ancient catastrophes. CNR Edizioni, Rome, pp 255-264

Barton NR (1974) A review of the shear strength of filled discontinuities in rock. Norwegian Geotech Inst Publ 105. Oslo, Norwegian Geotech Inst

Bosworth W, Huchon P, McClay K (2005) The Red Sea and Gulf of Aden Basins. J Afr Earth Sci 43:334378. https://doi.org/10.1016/j.jafrearsci.2005.07.020

British Standards Institution (2018) Geotechnical investigation and testing: identification, description and classification of rock part 1: identification and description (BS EN ISO 14689:2018)

Bunbury JM (2016) Geology of the Valley of the Kings. In: Wilkinson RH, Weeks KR (eds), The Oxford handbook of the Valley of the Kings, Oxford University Press, 15-22. https://doi.org/10.1093/oxfor dhb/9780199931637.013.40

Collins BD, Stock GM (2016) Rockfall triggering by cyclic thermal stressing of exfoliation fractures. Nat Geosci 9(5):395-400. https://doi.org/10.1038/ngeo2686

Corominas J, Mavrouli O, Ruiz-Carulla R (2018) Magnitude and frequency relations: are there geological constraints to the rockfall size? Landslides 15(5):829-845. https://doi.org/10.1007/s10346-017-0910-Z

Cross SW (2008) The hydrology of the Valley of the Kings. J Egypt Archaeol 94:303-310. https://doi.org/ $10.1177 / 030751330809400118$

Cruden DM, Varnes DJ (1996) Landslides: investigation and mitigation. Transp Res Board Special Rep 247:36-75

Curtis GH (1979) The geology of the Valley of the Kings, Thebes, Egypt. Theban Royal Tomb Project, The Brooklyn Museum Theban Expedition, pp 28

Dawson J (2003) Conservation of the "Tombs of the Nobles": aspects of the past, issues for the present. In: Strudwick N, Taylor JH (eds) The Theban necropolis: past, present and future. London, British Museum Press, pp 210-217

De Stefano R, Repola L, Guerriero L, Iovane D, Morra V, Pagano F, Di Martire D (2021) Rockfall threatening Cumae archeological site fruition (Phlegraean Fields Park-Naples). Sustainability 13(3):1390. https://doi.org/10.3390/su13031390

Delmonaco G, Margottini C, Spizzichino D, Khrisat B (2014) Rock slope potential failures in the Siq of Petra (Jordan). In: Sassa K, Canuti P, Yin Y (eds) Landslide Science for a Safer Geoenvironment. Springer, Cham, pp 341-347. https://doi.org/10.1007/978-3-319-04996-0_52

Demas M, Agnew N (2012) Valley of the Queens assessment report. A collaborative project of the Getty Conservation Institute and the Supreme Council of Antiquities, Egypt. Vol. 1, Conservation and Management Planning. Getty Conservation Institute, Los Angeles

Dorren LKA (2003) A review of rockfall mechanics and modelling approaches. Prog Phys Geogr: Earth Environ 27(1):69-87. https://doi.org/10.1191/0309133303pp359ra

Dorren LKA (2016) Rockyfor3D (v5.2) revealed - Transparent description of the complete 3D rockfall model. ecorisQ, pp 32

Dorren LKA, Berger F, Putters US (2006) Real size experiments and 3D simulation of rockfall on forested and non-forested slopes. Nat Hazards Earth Syst Sci 6:145-153. https://doi.org/10.5194/ nhess-6-145-2006

Dupuis C, Aubry MP, King C, Knox ROB, Berggren WA, Youssef M, Galal WF, Roche M (2011) Genesis and geometry of tilted blocks in the Theban Hills, near Luxor (Upper Egypt). J Afr Earth Sci 61(3):245-267. https://doi.org/10.1016/j.jafrearsci.2011.06.001

Eppes MC, Keanini R (2017) Mechanical weathering and rock erosion by climate-dependent subcritical cracking. Rev Geophys 55(2):470-508. https://doi.org/10.1002/2017RG000557

Eppes MC, Magi B, Hallet B, Delmelle E, Mackenzie-Helnwein P, Warren K, Swami S (2016) Deciphering the role of solar-induced thermal stresses in rock weathering. Bulletin 128(9-10):1315-38. https://doi. org/10.1130/B31422.1

Evans SG, Hungr O (1993) The assessment of rockfall hazard at the base of talus slopes. Can Geotechn J 30:620-636. https://doi.org/10.1139/t93-054

Evrard H, Guillaume A (1997) Analyse structurale et géotechnique de la tombe de Ramsès II - Vallée des Rois, Louqsor, Égypte. Memnonia 8:129-149

FOEN - Federal Office for the Environment (2016) Protection against mass movement hazards. Guideline for the integrated hazard management of landslides, rockfall and hillslope debris flows. The environment in practice: UV-1608-E, pp 97

Ferrari F, Giacomini A, Thoeni K (2016) Qualitative rockfall hazard assessment: a comprehensive review of current practices. Rock Mech Rock Eng 49:2865-2922. https://doi.org/10.1007/s00603-016-0918-Z 
Fielding L, Najman Y, Millar I, Butterworth P, Garzanti E, Vezzoli G, Barfod D, Kneller B (2018) The initiation and evolution of the River Nile. Earth Planet Sci Lett 489:166-178. https://doi.org/10.1016/j. eps1.2018.02.031

Gander P, Gugger F (1996) Geologische Karte Tal der Könige und Tal der Königinnen. Luxor, Ägypten, 1:5000. Geological mappings of P. Gander and F. Gugger in 1996, together with mappings of Lazar (1995) and Wüst $(1995,1996)$

Gerber W (2019) Naturgefahr Steinschlag - Erfahrungen und Erkenntnisse. Eidg. Forschungsanstalt für Wald, Schnee und Landschaft WSL, Birmensdorf. WSL Berichte 74, pp 149

Ghazipour N, Uromeihy A, Entezam I, Ansari F, Pirouz M (2008) The use of Cone-Fall theory for evaluation of rock-fall hazard along the Chaloos-Road (Pol-e-Zanguleh-Marzan-Abad). Geosciences 17(66):160-169. http://dx.doi.org/https://doi.org/10.22071/gsj.2008.57654

Guillaume A (2001-2002) Paramètres mécaniques des géomatériaux utilisables pour les modélisations numériques des hypogées de la Vallée des Rois (Louqsor, Égypte): essais géotechniques et réalité. Memnonia 12-13:143-190

Guillaume A (2004) Sur quelques images remarquables concernant l'hypogée de Ramsès II [KV.7] (Vallée des Rois, Louqsor, Égypte). Memnonia 15:197-201

Guillaume A, Emery-Barbier A, Cervelle-Zonca N (1995) Le remplissage sédimentaire de la tombe de Ramsès II. Memnonia 6:147-173

Guillaume A, Jeannette D, Paquet H, Serratrice SF (2001) Géotechnique de la formation d'Esna et conservation de la tombe de Ramsès II (Vallée des Rois, Louqsor, Égypte). Revue D'archéométrie 25:113-123

Guzzetti F, Reichenbach P, Wieczorek GF (2003) Rockfall hazard and risk assessment in the Yosemite Valley, California, USA. Nat Hazards Earth Syst Sci 3(6):491-503. https://doi.org/10.5194/ nhess-3-491-2003

Guzzetti F, Reichenbach P, Ghigi S (2004) Rockfall hazard and risk assessment along a transportation corridor in the Nera Valley, central Italy. Environ Manag 34:191-208. https://doi.org/10.1007/ s00267-003-0021-6

Heim A (1932) Bergsturz und Menschenleben. Fretz und Wasmuth Verlag, Zürich, p 218

Hemeda S (2021) Geo-environmental monitoring and 3D finite elements stability analysis for site investigation of underground monuments. Horemheb tomb (KV57), Luxor, Egypt. Herit Sci 9:17. https:// doi.org/10.1186/s40494-021-00487-3

Hudson JA, Harrison JP (1997) Engineering rock mechanics - an introduction to the principles. Pergamon Press, Amsterdam, p 444

Hungr O, Corominas J, Eberhardt E (2005) Estimating landslide motion mechanism, travel distance and velocity. In: Fell R, Couture R, Eberhardt E (eds) Hungr O. Landslide Risk Management, CRC Press, pp 99-128

Hungr O, Leroueil S, Picarelli L (2014) The Varnes classification of landslide types, an update. Landslides 11(2):167-194. https://doi.org/10.1007/s10346-013-0436-y

ISRM- International Society for Rock Mechanics and Rock Engineering (1981) Suggested Methods for the rock characterization, testing and monitoring. Pergamon Press, Oxford, pp 211

Jaboyedoff M, Dudt MP, Labiouse V (2005) An attempt to refine rockfall hazard zoning based on the kinetic energy, frequency and fragmentation degree. Nat Hazards Earth Syst Sci 5(5):621-632. https://doi.org/10.5194/nhess-5-621-2005

Jaboyedoff M, Labiouse V (2003) Preliminary assessment of rockfall hazard based on GIS data. In: Proceedings of 10th International Congress Rock Mechanics ISRM 2003. South African Institute of Mining and Metallurgy, Johannesburg, South Africa, 8-12 September 2003, pp 575-578

Jaboyedoff M, Labiouse V (2011) Preliminary estimation of rockfall runout zones. Nat Hazards Earth Syst Sci 11(3):819-828. https://doi.org/10.5194/nhess-11-819-2011

Karakhanyan A, Avagyan A, Sourouzian H (2010) Archaeoseismological studies at the temple of Amenhotep III, Luxor, Egypt. In: Sintubin M, Stewart IS, Niemi TM, Altunel E (eds) Ancient earthquakes (Geological Society of America Special Paper 471). Geological Society of America, Boulder, pp 199-222

Katz O, Reichenbach P, Guzzetti F (2011) Rockfall hazard along the railway corridor to Jerusalem, Israel, in the Soreq and Refaim valleys. Nat Hazards 56:649-665. https://doi.org/10.1007/s11069-010-9580-z

King C, Dupuis C, Aubry MP, Berggren WA, Knox RO, Galal WF, Baele JM (2017) Anatomy of a mountain: the Thebes Limestone Formation (Lower Eocene) at Gebel Gurnah, Luxor, Nile Valley, Upper Egypt. J Afr Earth Sci 136:61-108. https://doi.org/10.1016/j.jafrearsci.2017.05.008

Köppen WD (1936) Das geographische System der Klimate. In: Köppen W, Geiger R (eds), Handbuch der Klimatologie, Bd. 1: Teil C. Bornträger, Berlin, pp 44

Leblanc C (1995) Thèbes et les pluies torrentielles: à propos de mw n pt. Memnonia 5:197-214 
Lied K (1977) Rockfall problems in Norway. In: Rockfall dynamics and protective work effectiveness. Bergamo, ISMES publication 90:51-53

Loew S, Hantz D, Gerber W (2021) Rockfall causes and transport mechanisms: a review. In: Treatise of Geomorphology, 2nd edn, Elsevier. https://doi.org/10.1016/B978-0-12-818234-5.00066-3

Loye A, Pedrazzini A, Jaboyedoff M (2008) Preliminary regional rockfall hazard mapping using lidarbased slope frequency distribution and conefall modelling. In: Proc 4th Canad Conf Geohazards, Laval University Press, Quebec 20-24 May 2008, pp 8

Marinos V, Marinos P, Hoek E (2005) The geological strength index: applications and limitations. Bull Eng Geol Environ 64(1):55-65. https://doi.org/10.1007/s10064-004-0270-5

Matasci B, Stock GM, Jaboyedoff M, Carrea D, Collins BD, Guérin A, Matasci G, Ravanel L (2018) Assessing rockfall susceptibility in steep and overhanging slopes using three-dimensional analysis of failure mechanisms. Landslides 15(5):859-878. https://doi.org/10.1007/s10346-017-0911-y

McLane J, Wüst RA, Porter B, Rutherford J (2003) Flash-flood impacts and protection measures in the Valley of the Kings, Luxor, Egypt. APT Bull 34:37-45

Mineo S, Pappalardo G (2020) Sustainable fruition of cultural heritage in areas affected by rockfalls. Sustainability 12(1):296. https://doi.org/10.3390/su12010296

Mohamed Abuo El-Ela A, El-Hadidy M, Deif A, Abou Elenean K (2012) Seismic hazard studies in Egypt. NRIAG J Astron Geophys 1-2:119-140. https://doi.org/10.1016/j.nrjag.2012.12.008

Ogiso Y, Sumi T, Kantoush S, Saber M, Abdel-Fattah M (2017) Risk assessment of flash floods in the Valley of the Kings, Egypt. DPRI Annuals 60(B):864-874

Onofri R, Candian C (1979) Indagine sui limiti di massima invasione di blocchi rocciosi franati durante il sisma del Friuli del 1976. Reg. Aut. Friuli - Venezia Giulia, CLUET. Trieste, pp 42

Palma B, Parise M, Reichenbach P, Guzzetti F (2012) Rockfall hazard assessment along a road in the Sorrento Peninsula, Campania, southern Italy. Nat Hazards 61:187-201. https://doi.org/10.1007/ s11069-011-9899-0

Pappalardo G, Imposa S, Mineo S, Grassi S (2016) Evaluation of the stability of a rock cliff by means of geophysical and geomechanical surveys in a cultural heritage site (south-eastern Sicily). Ital J Geosci 135(2):308-323. https://doi.org/10.3301/IJG.2015.31

Pawlikowski M, Wasilewski M (2004) Some remarks on jointing in the Theban limestones in the region of Deir el-Bahari, Egypt. Geologia 30(1):47-56

Pérez-Rey I, Riquelme A, González-deSantos LM, Estévez-Ventosa X, Tomás R, Alejano LR (2019) A multi-approach rockfall hazard assessment on a weathered granite natural rock slope. Landslides 16(10):2005-2015. https://doi.org/10.1007/s10346-019-01208-5

Porcelli F, Sambuelli L, Comina C, Spanò A, Lingua A, Calantropio A, Catanzariti G, Chiabrando F, Fischanger F, Maschio P, Ellaithy A (2020) Integrated geophysics and geomatics surveys in the Valley of the Kings. Sensors 20(6):1552. https://doi.org/10.3390/s20061552

Reeves CN, Wilkinson RH (1996) Complete Valley of the Kings. Thames \& Hudson, p 224

Romer J (1975) The tomb of Tuthmosis III. Mitteilungen Des Deutschen Archäologischen Instituts, Abteilung Kairo 31:315-351

Rutherford J, Ryan DP (1995) Tentative tomb protection priorities, Valley of the Kings, Egypt. In: Wilkinson RH (ed), Valley of the sun kings: new explorations in the tombs of the pharaohs. Papers from the University of Arizona International Conference on the Valley of the Kings. Tucson: University of Arizona Egyptian Expedition, 134-156

Said R (1960) Planktonic foraminifera from the Thebes formation, Luxor. Egypt Micropaleontology 6(3):277-286. https://doi.org/10.2307/1484234

Said R (1962) The geology of Egypt. Elsevier, Amsterdam, p 377

Saroglou H, Marinos V, Marinos P, Tsiambaos G (2012) Rockfall hazard and risk assessment: an example from a high promontory at the historical site of Monemvasia. Greece Nat Hazard Earth Syst Sci 12(6):1823-1836. https://doi.org/10.5194/nhess-12-1823-2012

Tawfik HA, Zahran EK, Abdel-Hameed AT, Maejima W (2010) Mineralogy, petrography, and biostratigraphy of the Lower Eocene succession at Gebel El-Qurn, West Luxor, Southern Egypt. Arab J Geosci 4(3-4):517-534. https://doi.org/10.1007/s12517-010-0158-6

Varnes DJ (1978) Slope movement types and processes. In: Schuster RL, Krizek RJ (eds), Landslides, analysis and control. Transportation Research Board, Special Report 176, National Academy of Sciences, Washington, DC, 11-33

Volkwein A, Schellenberg K, Labiouse V, Agliardi F, Berger F, Bourrier F, Jaboyedoff M (2011) Rockfall characterization and structural protection: a review. Nat Hazards Earth Syst Sci 11(9):26172651. https://doi.org/10.5194/nhess-11-2617-2011

Whalley WB (1984) Rockfalls. In: Brunsden D, Prior DB (eds) Slope instability. Wiley, Chichester, pp $217-256$ 
Wieczorek GF, Snyder JB (1999) Rockfalls from Glacier Point above Camp Curry, Yosemite National Park, California. US Geological Survey Open-file Report 99-385, pp 13. https:/doi.org/https://doi. org/10.3133/OFR99385

Wüst RAJ (1995) Geologisch-geotechnische Untersuchungen im Thebanischen Gebirge Teil Süd, Luxor, Ägypten. M.Sc. Thesis, Universität Bern

Wüst RAJ, McLane J (2000) Rock deterioration in the royal tomb of Seti I, Valley of the Kings, Luxor, Egypt. Eng Geol 58(2):163-190. https://doi.org/10.1016/S0013-7952(00)00057-0

Wyllie DC (2014) Rock fall engineering. CRC Press, pp 270. https://doi.org/10.1201/b17470

Yehia, MA, Abdallah AM, Hamroush H (1982) Geomorphology of the Nagada Region Upper Egypt. Quatar University. Sci Bull 2:251-262. http://hdl.handle.net/10576/7801

Youssef AM, Maerz NH (2009) Slope stability hazard assessment and mitigation methodology along eastern desert Aswan-Cairo highway. Egypt JKAU: Earth Sci 20(2):161-181

Ziegler M, Colldeweih R, Wolter A, Loprieno-Gnirs A (2019) Rock mass quality and preliminary analysis of the stability of ancient rock-cut Theban tombs at Sheikh 'Abd el-Qurna, Egypt. Bull Eng Geol Environ 78(8):6179-6205. https://doi.org/10.1007/s10064-019-01507-0

Ziegler M, Loew S, Moore JR (2013) Distribution and inferred age of exfoliation joints in the Aar Granite of the central Swiss Alps and relationship to Quaternary landscape evolution. Geomorphology 201:344362. https://doi.org/10.1016/j.geomorph.2013.07.010

Publisher's Note Springer Nature remains neutral with regard to jurisdictional claims in published maps and institutional affiliations. 